\title{
El Cableado Neuronal Innato de Pinker Repudia la Cultura: Intertextualidad e Intersexualidad ${ }^{1}$
}

\author{
José A. Nieto y Luis Castro Nogueira² \\ Dpto. Sociología I UNED \\ janieto@poli.uned.es \\ lcastro@poli.uned.es
}

Recibido: 17.10 .2005

Aceptado: 06.04.2006

\section{VARIACIONES SOBRE PINKER Y LA TABULA RASA: NATURALEZA Y CULTURA}

Steven Pinker, prestigioso psicolinguiista que ha desarrollado la mayor parte de su carrera científica en el MIT, aunque en la actualidad imparte docencia como "Johnstone Professor" de Psicología en la Universidad de Harvard, sugiere en su último libro La tabla rasa: la negación moderna de la naturaleza humana, la incapacidad del modelo estándar en ciencias sociales para asumir alguna forma de naturaleza humana ${ }^{3}$. Los seis libros que ha publicado, entre los que destacan El Instinto del Lenguaje (Pinker, 1996) y Cómo trabaja la mente (Pinker, 2004), le han ido convirtiendo poco a poco en uno de los divulgadores científicos de mayor éxito y en un acreditado defensor de los principios de la psicología evolucionista. Aunque consciente de que el debate ideológico naturaleza versus cultura está muy trillado y de que ha dejado paso a un estudio más sereno de la interacción entre genes y cultura rico en nuevas hipótesis y planteamientos, Pinker manifiesta en el prefacio de su libro que su intención es hacer una defensa inequívoca de aquellos autores que todavía hoy sufren críticas durísimas por el simple hecho de sugerir que la herencia puede desempeñar algún papel en la gé-

${ }^{1}$ Para los autores que firman el presente artículo, José A. Nieto y Luis Castro Nogueira, La tabla rasa. La negación moderna de la naturaleza humana, de S. Pinker puede adquirir la relevancia social y académica que tuvo, en su momento, la publicación de Sociobiología de E. O. Wilson. La radicalidad de los planteamientos de Pinker es muy controvertible, sus argumentos requieren ser debatidos y, para Nieto y Castro, dado la significación que concitan para las ciencias sociales, sus tesis fundamentales han de ser sometidas a una crítica rigurosa y detallada. Partiendo de esta iniciativa, se presenta este texto con el ánimo, a su vez, de que sea ulteriormente respondido.

Esperamos de esta manera contribuir a relanzar el ahora casi desterrado debate académico.

${ }^{2}$ Las firmas son intercambiables. El hecho de que aparezcan en este orden se debe a la deferencia del profesor Castro.

${ }^{3}$ Otra versión de estas ideas aparece en Castro Nogueira, Laureano et alia (2005) 
nesis de la conducta y el pensamiento humano. El problema proviene según Pinker de que cualquier propuesta que avale una organización innata para la mente es atacada sin miramiento no por el hecho de que pueda ser errónea, sino porque se considera un pensamiento cuya concepción es inmoral, tal y como ocurría en las polémicas de los años 70. Con sus propias palabras: "Mi objetivo en este libro no es defender que los genes lo son todo y la cultura no es nada -nadie cree tal cosa-, sino analizar por qué la postura extrema - la de que la cultura lo es todo- se entiende tan a menudo como moderada, y la postura moderada - a saber: que en la mayoría de los casos la explicación correcta surgirá de una interacción compleja entre herencia y ambiente- se ve como extrema" (Pinker, 2003: 13). Recalca Pinker, con razón, que el reconocimiento de que la naturaleza humana juegue un papel en la determinación de la conducta no implica, desde un punto de vista lógico, los resultados negativos que tantos temen. Incluso va más allá y aboga por la tesis, siguiendo la optimista sentencia de Chejov "el hombre será mejor cuando se le muestre cómo es", de que la influencia que pueden tener las nuevas ciencias de la naturaleza humana encabezando la marcha hacia un humanismo realista e informado biológicamente puede resultar beneficiosa en el afán de alcanzar una sociedad mejor.

Para lograr su propósito Pinker construye, a lo largo de las seis partes en las que se estructura el libro que vamos a debatir, tres argumentos principales. Primero, hace un diagnóstico sobre los motivos que han llevado a considerar inmoral y perniciosa toda referencia a la naturaleza humana, alentando reacciones desmesuradas contra cualquier teoría alternativa. Este es sin duda el meollo del libro y sus explicaciones, si bien se extienden a lo largo del texto, se concentran sobre todo en las dos primeras partes ${ }^{4}$. El segundo argumento, visible también en buena parte de la obra y muy especialmente en la parte tercera y en el capítulo final $^{5}$, sostiene que el cambio de paradigma que se propone es, además de necesario, menos peligroso y revolucionario de lo que parece. Por último, defiende en las partes cuarta y quinta ${ }^{6}$ la tesis de que una concepción más rica de la naturaleza humana, basada en los enfoques de la psicología evolucionista -el libro está dedicado a cuatro de sus más distinguidos representantes--, puede aportar nuevas hipótesis y conceptos sobre la evolución del lenguaje, el pensamiento, la vida social y la moral y también iluminar eficazmente importantes aspectos en conflicto en el ámbito de los estudios sobre política, violencia, género, educación $o$ arte. En lo que sigue desarrollaremos críticamente algunas de estas ideas, haciendo una valoración de lo que entendemos como aciertos y errores en sus propuestas, esbozando en ocasiones una reflexión alternativa que, siendo respetuosa con los presupuestos evolucionistas que maneja Pinker, conduce a conclusiones diferentes.

4 Tituladas La tabla rasa, el buen salvaje y el fantasma en la máquina (25-166) y Miedo y recelo (167-214).

${ }^{5}$ La tercer parte se titula La naturaleza humana con rostro humano $(215-292)$ y el último capítulo La voz de la especie (609ss).

${ }^{6}$ Tituladas, respectivamente, Conócete a ti mismo (293-412) y Los temas candentes (413-626)

EMPIRIA. Revista de Metodología de Ciencias Sociales. N. ${ }^{\circ} 11$, enero-junio, 2006, pp. 133-171. ISSN: 1139-5737 


\section{EI secreto mejor guardado de la naturaleza humana}

En casi todas las culturas conocidas las mujeres se consideran intelectual y moralmente inferiores a los hombres y condenadas a tareas de menor rango social como el cuidado doméstico. Asimismo, en todas las culturas conocidas se detectan estereotipos racistas sobre la inferioridad de otros pueblos. ¿Cuál es la naturaleza de estos clichés sobre el sexo y otros pueblos? Probablemente, un tipo de racionalidad basada en valores (superioridad física masculina y etnocentrismo, por ejemplo) que tiende a perpetuarse como un peculiar sistema de herencia. Racionalidad que sistemáticamente modifica cualesquiera disonancias cognitivas para mantener intactos esos mismos prejuicios, clichés e imaginarios sociales.

El propio libro de Pinker es una extraordinaria muestra de este tipo de racionalidad plagada de sesgos axiológicos, centrada en nociones distorsionadas como la tabla rasa, el buen salvaje y el fantasma en la máquina ${ }^{7}$. En efecto, descontextualizadas (como molinos de viento convertidos en amenazadores gigantes), y convenientemente distorsionadas y magnificadas a efectos retóricos, estas representaciones sociales (iy su contradictoria sinergia!), propagadas (se nos advierte) por taimadas feministas, ingenuos antropólogos, psicólogos conductistas y científicos de filiación marxista (Lewontin, Rose y Gould), terminan por dar la sensación en el desprevenido lector de una Gran Conspiración En Marcha destinada a ocultar (durante los últimos cincuenta años) la existencia misma de una naturaleza humana.

No importa que para ello haya que prescindir de la sensata radicalidad de la mayor parte del feminismo histórico; obviar que la pretendida ingenuidad de los antropólogos apunta a explorar otras dimensiones de la naturaleza humana compatibles (a veces) con las reivindicaciones de Pinker; ignorar la poderosa influencia del psicoanálisis a la hora de concebir una naturaleza humana al menos tan contundente como la judeocristiana y mirar para otro lado cuando se trata de demonizar a biólogos progresistas opuestos a interpretaciones interesadas, conservadoras y retrógradas de ciertos resultados sociobiológicos.

\section{El ajuste de cuentas con Lewontin, Rose y Gould}

En dos capítulos provocadoramente titulados Los políticos científicos y $\mathrm{La}$ santísima trinidad se pasa revista y, finalmente, se procede a un violento ajuste de cuentas con las ideas marxistas del prestigioso genetista Lewontin y el neurobiólogo Rose, así como con las opiniones progresistas (menos doctrinarias) del paleontólogo Gould. De pronto, el texto deja de ser aceptable divulgación científica para convertirse en acerbo panfleto armado de todos los artificios retóricos

${ }^{7}$ La expresión remite a la célebre metáfora The Ghost in the machine, usada por G Ryle en su libro The Concept of the Mind, última edición castellana El concepto de lo mental, Paidós, Barcelona, 2005. 
para desacreditar a sus rivales. En la estela de decepcionantes recuerdos estudiantiles del joven Pinker, en el Harvard progresista de los años setenta, la biología dialéctica y sus referencias a Marx, Engels y Mao, se presenta como una improbable y fatal reencarnación de la santísima trinidad: la tabla rasa, el buen salvaje y el espíritu en la máquina. El texto parece construido para que, finalmente, los tres ingredientes confluyan como la encarnación del mal en su cerril oposición (propia del izquierdismo radical) a los avances de las nuevas ciencias de la naturaleza humana.

El motivo es la oposición de Lewontin y Rose a las connotaciones políticas de la sociobiología, surgidas después de la publicación del libro del mismo título de Wilson en 1975. Ambos científicos (en su supuesta ceguera ideológica, inspirada por la santísima trinidad) habrían ridiculizado descubrimientos esenciales de Hamilton (sobre la genética del altruismo), del propio Wilson y de Dawkins (en su libro El gen egoísta) tergiversando los hechos para desacreditar como fascistas y neoconservadores a sus oponentes. No podemos entrar en la letra de estas reyertas político/académicas a la hora de evaluar quién caricaturiza más a quién (Pinker reconoce que algunas gravísimas afirmaciones de Wilson sobre el sentido moral de nuestra especie eran completamente erróneas y, añadimos nosotros, peligrosas políticamente). Nos interesa plantear algo más esencial (al menos para los biólogos radicales) y que Pinker parece incapaz de digerir. En efecto, en su texto escrito con Kamin, No está en los genes, Lewontin y Rose se autoproclaman no sólo científicos de inspiración marxista sino también empeñados en que sus aportaciones intelectuales contribuyan a una sociedad socialista más justa e igualitaria. Por todo ello (y con militante autoconciencia), su examen de la atmósfera ideológica que rodea a la sociobiología de los años setenta y ochenta apunta a desactivar cualquier tentación de reificar en forma de naturaleza humana un orden social que consideraban injusto. Evidentemente, tampoco se trata ahora, por nuestra parte, de revelar las posibles ilusiones e ingenuidades de aquellos biólogos dialécticos sino de constatar que sus intervenciones eran legítimamente filosóficas y no sólo de orden técnico.

Frente a ellos, Pinker incurre en una falacia que naturaliza el significado de ciertas realidades sociopolíticas. Podemos denominar a este sofisma culturaleza o identificación de un modelo de sociedad con el verdadero destino (positivo o negativo) de la auténtica naturaleza humana. Se trata en este caso de mostrar cómo los regímenes de tipo soviético o maoísta se habrían estrellado (por su ingenua creencia en la maleabilidad radical de las conductas: la tabula rasa) contra la protesta de una sustancia humana irreductible a los ideales comunistas. En una palabra: la culturaleza comunista sería incompatible con la condición humana. En palabras de Wilson (padre de la sociobiología) el marxismo sería una teoría magnífica, pero aplicada a una especie equivocada, y, en versión pinkeriana, la ambición de rehacer la naturaleza humana convirtió a sus líderes en déspotas totalitarios y en asesinos de masas (Pinker, Ibidem: 431). La barbarie totalitaria (por razones retóricas) se transmuta en (supuesta) exquisita inopia socrática: para Pinker, en este caso, la atrocidad es ignorancia. 
Sabemos que no es así. Eso que llamamos condición humana (para bien y para mal) es compatible con las frecuentes guerras entre los Yanomamo, la caridad cristiana, los grandes imperios hidráulicos de la antigüedad, el estalinismo, el nazismo, el capitalismo liberal que condujo a la crisis del año 1929, y su corrección keynesiana que alumbró el estado del bienestar. La derrota del socialismo real nada tiene que ver con ningún déficit epistemológico sobre los límites de la naturaleza humana atribuible a la teoría o a la praxis marxista, sino con su incapacidad de competir con los regímenes del capitalismo democrático (en una sociedad crecientemente tecnológica) creando niveles comparables de industria militar, prosperidad y bienestar, y (paralelamente) con el implacable deterioro que sufrieron los ideales revolucionarios (evidencia de crímenes políticos, nomenklaturas, Archipiélagos GULAG y miseria ideológica).

Los graves errores del marxismo se derivan, en todo caso, de haber alumbrado un puñado de teológicas fantasías (que, a la postre, se revelaron fatales) sobre inmanencias e inminencias de la historia, lucha y conciencia de clases, epistemología dialéctica, ideologías (falsa y verdadera conciencia) y dictaduras del proletariado. El fallo de los radicalismos de la izquierda no ha sido tanto una carencia (su pretendida incapacidad de reconocer la existencia de una naturaleza humana) como un exceso o hybris: haberse dejado fascinar por deslumbrantes paisajes imaginarios sobre la Historia de los hombres, haberse instalado a los mandos de esa misma Historia y haber procedido resuelta (y, a menudo, despoticamente) a su realización material.

Por todo ello, podemos resumir las escaramuzas político académicas del binomio naturaleza / cultura de la siguiente manera que modifica sustancialmente el relato pinkeriano:

1. La derecha clásica (nazi, conservadora: incluida la versión más heavy de Pinker), racista y fundamentalista, dice despreciar la esfera cultural (aunque se cuida mucho de mimar cuidadosamente el habitus que garantiza su reproducción como clase), dictaminando que las diferencias entre los seres humanos se deben a una fatal naturaleza que a unos hace fuertes y a otros débiles, a unos inteligentes y a otros necios, a unos blancos y a otros negros y a unos hombres y a otros mujeres. Las culturas reflejarían las diferentes dotaciones genéticas de pueblos e individuos y explicarían el dominio de unos sobre otros. Esta derecha clásica, cosifica y naturaliza todavía más si cabe la naturaleza, incurriendo en una variante de la clásica falacia naturalista que podemos denominar falacia de la natura naturata (interpretación de las diferencias y valores culturales como fatalidades naturales: todo en el fondo es y se reduce a naturaleza genética).

2. La derecha ilustrada (Wilson, otros sociobiólogos y el propio Pinker en versión light), reivindica una tabula con más texturas que la izquierda pero coquetea, igualmente, con fantasías sobre el mundo cultural que tienden a ver en la actual sociedad (abierta, popperiana, democrática y de mercado) la puesta de largo de la única y más verdadera naturaleza hu- 
mana que, por fin, podría revelarse en todo su esplendor, belleza, complejidad, libertad y contundencia. Rondan aquí los fantasmas hegelianos (recordemos las tesis sobre el fin de la historia de Fukuyama) así como cierta naturalización del mundo sociopolítico contemporáneo. En el fondo, se nos sugiere, sólo las actuales sociedades opulentas permiten que se manifieste la verdadera naturaleza humana. Estamos ante la falacia de la naturatura que naturaliza el imaginario neoliberal.

3. La izquierda ilustrada radical (incluidos Lewontin, Rose y Kamin, por mantenernos dentro de la narrativa de Pinker), más que suscribir el modelo de la tabula rasa negador de la naturaleza humana, a menudo ha hipostasiado y cosificado el devenir del mundo histórico-cultural, creyendo descifrar en los azares de los asuntos humanos rumores teleológicos y destellos de orden dialéctico que apuntaban inexorablemente hacia la posibilidad de una sociedad sin clases. Esta izquierda, arropada por Hegel/ Marx, naturaliza como una deseable, inminente e inexorable fatalidad histórica la reapropiación por los hombres de su propia (definitiva) esencia. En el fondo, se nos sugiere, la única naturaleza humana es su historia sociocultural, la historia natural de la definitiva liberación del hombre. Tampoco en este caso quedan muy lejos los espectros neohegelianos y el comienzo de la verdadera historia de la humanidad. Falacia de la culturaleza.

4. El modelo estándar de las ciencias sociales (en algunas de sus versiones más radicales) también parece reificar el mundo cultural, hipostasiando en exceso su consistencia ontológica al margen de los individuos y de sus procesos de socialización, dificultando a menudo la explicación del cambio social. Este modelo (en su máxima expresión) tiende a considerar a la cultura como la única naturaleza humana. Todo en el fondo (se reduce a) y es cultura: falacia de la cultura culturata.

En las democracias modernas, sostiene Pinher, no existen las hambrunas, casi no se declaran la guerra entre ellas y son la principal aspiración de las personas de todo el mundo (431). Pinker (empujado por un místico crescendo orientado a la transustanciación de la naturaleza humana en neoliberalismo) llega al delirio de considerar la Constitución americana como seráfica revelación de todo aquello que las ciencias cognitivas, neurológicas, genéticas y psicoevolutivas han mostrado, definitivamente, como lo más aprovechable de nuestra condición: desde un sabio altruismo recíproco con controles para gorrones y estafadores, hasta los más sutiles mecanismos sociobiológicos que regularían el equilibrio entre el instinto de dominio, el amor propio y la solidaridad. El jurista McGinnis (en quién se inspira Pinker) dictamina que la teoría de la naturaleza humana de los fundadores se podría haber derivado directamente de la moderna psicología evolutiva (Ibidem: 432). He aquí la falacia de la natucultura en todo su esplendor.

Es bien cierto (y Pinker debería saberlo), que el genocidio de los nativos americanos, la esclavitud, la segregación racial y la negación del voto a las mu- 
jeres no sintonizan muy bien con ese hechizo eucarístico entre naturaleza humana y origen de América, pero (como reconoce el propio Pinker), al parecer, todo ello sucedió debido al círculo moral manifiestamente reducido de aquellos tiempos (Ibidem: 434). ¡Si llega a ser ahora!

En resumen: según Pinker, la izquierda radical (incapaz, al parecer, de vislumbrar las auténticas promesas de la naturaleza humana) tendría que disculparse eternamente por sus ignorancias y barbaries, pero, (se nos sugiere) todavía existiría un espacio para una izquierda darwinista capaz de extraer las conclusiones políticas arrojadas por las nuevas ciencias de la naturaleza humana. Esa nueva izquierda (i!) debería aceptar y reconocer natu(cultu)ralmente a la sociedad neoliberal como el mejor de los mundos posibles y proponer (jreconvirtiéndose en una suerte de inofensiva ONG sociobiológica!), pequeñas reformas fiscales y educativas para compensar las diferentes dotaciones de los individuos.

\section{Barbarie y genocidio: totalitarismo racista y totalitarismo de la tabula rasa}

Ante la incapacidad de pensar los imaginarios sociales como diferentes racionalidades ancladas en representaciones cargadas de deseos, emociones y valores (producto de la doble dimensión de la cultura), Pinker pretende ajustar las cuentas con el nazismo y los despotismos rojos en términos de dos lógicas diferentes sobre la naturaleza humana que sólo tendrían un punto en común. Esa única coincidencia apuntaría a un deseo compartido de reconfigurar la humanidad (en un caso con el triunfo de la raza aria y en otro con el del proletariado), un parecido idealismo revolucionario y una idéntica resolución tiránica a la hora de llevarlo a la práctica. Pero, a partir de ese momento existirían enormes diferencias.

En el caso de Hitler, su racismo (su idea de una naturaleza humana determinada por la genética) debe separarse por completo de sus crímenes, es decir, el holocausto no se deriva de su darwinismo social: Hitler era perverso porque causó la muerte de treinta millones de personas y un sufrimiento inimaginable a otro sinfin de ellas, no porque sus creencias hicieran referencia a la biología (...) Las ideas están conectadas con otras ideas, y si resulta que alguna de las de $\mathrm{Hi}$ tler tiene algo de verdad-si resulta, por ejemplo, que las razas tienen algún tipo de realidad biológica, o si los indoeuropeos fueron realmente una tribu conquistadora- no vamos a conceder que a pesar de ello el nazismo no fuera un error (234-5).

Sin embargo, de nuevo, jay!, en el caso de las atrocidades rojas, la cosa cambia radicalmente. Los textos de Marx (la verdadera naturaleza del hombre es la totalidad de las relaciones sociales), Mao (una hoja de papel en blanco no tiene borrones) y los jemeres rojos (sólo el recién nacido no tiene mancha), son sobrecogedoramente explícitos y parecen atribuir a la pérfida doctrina de la tabula rasa la responsabilidad definitiva de tantos execrables crímenes. Esta vez, la nefasta idea (i!) de la negación de la naturaleza humana (que Pinker con su libro 
pretende, piadosamente, enmendar) muestra bien a las claras su inexorable compromiso con la artera legitimación de millones de muertos, genocidios y sufrimientos a una escala desconocida en la historia de los hombres.

Si la maldad de Hitler era independiente de sus ideas racistas, la iniquidad de Mao o Pol Pot ha de estar exclusivamente ligada a una de ellas: la tabula rasa, y, con esta finta dialéctica, Pinker recurre y se acoge, ahora, al modelo estándar de las ciencias sociales que tanto había denostado antes y que disuelve al individuo. En efecto, de pronto, las mentes de Stalin, Mao o Pol Pot se desinflan de contenido hasta devenir puros recipientes vacíos sobre los que se cierne un fetiche reificado, autosubsistente y flotante (al modo de un espíritu supraorgánico): la nefanda tabula rasa, causa de todos los males.

Este mismo esquematismo retórico y autocontradictorio subyace a la hora de explicar cualquier otro fenómeno como la violencia o las diferencias de género, de acuerdo con la siguiente lógica:

1. Se critican (a menudo con sensatez y eficacia) los tópicos de la corrección política que pretenden negar la existencia de ciertos universales sociopolíticos inscritos virtualmente en nuestra naturaleza, el carácter a menudo violento de la misma o las naturales diferencias de género. Se nos advierte una y otra vez que la tabula rasa, latente en la psicología y el modelo estándar en ciencias sociales, tendría la máxima responsabilidad epistemológica en tales desvaríos.

2. Se presentan los respectivos universales psicobiológicos, advirtiéndonos de su inexorable y funesto alcance: el comunismo es antinatural, jamás existirá una sociedad no violenta o las mujeres nunca podrán escapar a su condición.

3. Se intenta demostrar que la naturatura de la sociedad neoliberal es la organización social que más y mejor minimiza los posibles letales efectos de estos universales sobre el destino de nuestra especie.

4. Se elige, entonces, un chivo expiatorio que convierta la responsabilidad epistemológica de la tabula rasa (del modelo estándar) en culpabilidad histórico-social: asesinos marxistas, ingenuos pacifistas y resentidas archifeministas aparecen como previsibles viáticos de la encarnación de abyectas pestilencias.

5. En este punto, so pena de arruinar las plusvalías retóricas de la argumentación anterior, se erradica de un plumazo cualquier vestigio de naturaleza humana (supuestamente ganado en el punto 2) en la conducta de marxistas, pacifistas y archifeministas y se vacía a las mentes de unos y de otras de cualquier mínima entidad neurológica evolutiva para convertirlos en puros recipientes y transmisores de una barbarie vírica y memética: la tabula rasa.

6. De esta guisa, aplicando, ahora, inconscientemente el (antes abominado) modelo estándar de ciencias sociales que prescinde de mentes e individuos, se fabrica un fetiche capaz de anudar responsabilidades epistemo- 
lógicas e históricas y que encarna los males que acechan a la naturaleza del hombre.

7. Finalmente, entra Pinker en escena (joven héroe matador del dragón materno) con el libro que podrá definitivamente las cosas en su sitio, exorcizando a ese pernicioso fantasma, causa y origen de las desventuras de América y del resto del mundo civilizado.

\section{Las artes}

Nada tiene de extraño por todo ello que se abomine del modernismo en las artes al romper con la perspectiva renacentista y otras convenciones formales (incluida la noción tradicional de belleza) como una desviación elitista, abstrusa y forzada de las naturales formas de percibir y representarnos el mundo. Como era previsible, Pinker dictamina que las teorías dominantes del arte y la crítica de élite del siglo $X X$ surgieron de una negación militante de la naturaleza humana (603). Los seguidores de estetas y teóricos como T. Adorno y M. Foucault (con su refinado desprecio por el gusto mercantil de las masas) serían los ganadores habituales del Concurso Anual de Redacción con un Mal estilo que premia los pasajes de estilo más lamentables de los libros y artículos ensayísticos (603).

Ciertamente, según Pinker (que cita una encuesta para evaluar el gusto artístico de los estadounidenses) existe una atracción estética universal hacia los paisajes de calendarios con niños, ciervos (...) paisajes realistas, de pincelada suave y colores verdes y azules y en los que aparecen animales, mujeres, niños y figuras heroicas (...) como George Washington (593). Al parecer, la estética evolutiva (jsic!) señalaría tales obras como el tipo de paisaje óptimo para nuestra especie ( sic!) (593).

Sería interesante que Pinker (más allá de simplezas para un público al que simultáneamente halaga y degrada) nos explicase la paradoja de que Stalin, Mao y Pol Pot (máximos artífices, según él, de una ingeniería social inspirada en la tabula rasa y en la maleabilidad de la mente humana) coincidan, sin embargo, con el propio Pinker en su oposición al modernismo y en su cerrada defensa ( ¡ bajo pena de muerte!) de esa vuelta al clasicismo naturalista más convencional.

Sin embargo, lo decisivo en el campo de la estética no es tanto la virtual presencia de universales del gusto como la comprensión de hasta qué punto, por ejemplo, las formas cubistas y sus legitimaciones filosóficas y de cualquier otro orden permiten la creación de sutiles campos discursivos (y goces estéticos) tan sólidos y estables como los del realismo de Millet, el manierismo del Greco, las vírgenes góticas o la estatuaria de Praxiteles. 


\section{La imposible sinergia entre la tabula rasa, el buen salvaje y el fantasma en la máquina}

La tabula rasa de Locke, como reconoce Pinker, no sólo fue una genialidad epistemológica frente a las ideas innatas cartesianas y la omnipresente tradición teológica, sino también una espléndida metáfora para socavar la legitimidad del antiguo régimen y el derecho divino de los reyes, abriendo el camino a las modernas democracias. Si en asuntos humanos la experiencia y la educación lo eran todo, quedaba expedito todo un programa de mejora y perfeccionamiento de los seres humanos que culmina con la divisa kantiana sapere aude.

Pero lo sorprendente es que, a pesar de todo ello, tanto Locke como Kant, Nietzsche, Marx o Freud, fueron incapaces de remontar fantasías falocráticas milenarias sobre la inferioridad intelectual y moral de la mujer. Algo que, finalmente, tuvieron que hacer (a veces de manera militante) los grupos feministas. Y algo parecido ocurrió con las diferencias étnicas y la supuesta inferioridad de otros pueblos, pese al testimonio de la mayoría de los antropólogos. Todo apunta a que la tabula rasa y su apuesta por el carácter determinante de educación y experiencia a la hora de definir la condición humana fue algo tan asombroso e impensable que sobrepasó con creces la imaginación de los propios ilustrados.

Por otro lado, el dualismo cartesiano del fantasma en la máquina no sólo no se lleva bien con la tabula rasa de Locke en términos epistemológicos al defender una naturaleza espiritual innata (como sabe cualquier estudiante de bachillerato) sino que supone una concepción infinitamente más determinista de la naturaleza humana que la defendida por Pinker y los sociobiólogos más extremistas.

En efecto, el mecanicismo del siglo XVII apenas vislumbraba la posibilidad de pensar el libre albedrío, obsesionado como estaba por fantasías de animales/hombres máquina. Probablemente no haya existido ninguna época más preocupada por una naturaleza tan matemáticamente inexorable y fatalista como la que se manifiesta en las obras de los pensadores del barroco. Realmente, la postulación del espíritu en la máquina es inseparable del terror cartesiano ante el significado y las consecuencias de un orden mecánico y geométrico del mundo. Los delirios matemáticos de Hobbes y Spinoza sobre la calculabilidad de las pasiones del alma van por ahí. Por lo demás, el dualismo cartesiano no representa otra cosa que la necesidad de armonizar los descubrimientos de la ciencia moderna con la pervivencia de una poderosa naturaleza humana de origen judeocristiano.

En una palabra, el espíritu en la máquina (como denominó Ryle al cartesianismo) es una metáfora para poder pensar al mismo tiempo la máquina (una naturaleza humana percibida como terrible amenaza para la libertad y la salvación del alma) y la responsabilidad personal. Por ello, tanto el dualismo cartesiano como su original modelo judeocristiano, no sólo son clamorosamente incompatibles con la tabula rasa que interesa a Pinker (la maleabilidad radical de la mente humana urdida por los agentes del mal ya mencionados), sino que representan 
justamente la afirmación más contraria a la misma, a saber: una condición humana pesimista, envenenada y corrompida por las pasiones, la culpa, el pecado y el mal.

De ahí el escepticismo que embarga a cualquier lector a la hora de pensar la tabula rasa y el espíritu en la máquina como improbables responsables solidarios de la supuesta negación de la naturaleza humana a lo largo de los últimos siglos.

Por otro lado, si el buen salvaje de Rousseau ha iluminado muchos caminos de las modernas libertades, el homo homini lupus de Hobbes no le va a la zaga como simétrica legitimación y canonización sociológica de las servidumbres de pueblos e individuos. En la modernidad se alternan ambos imaginarios a la hora de legitimar el orden/desorden social.

Hipostasiar el buen salvaje como epítome de todos los idealismos que conducen inapelablemente a las ingenierías sociales del archipiélago Gulag y los jemeres rojos, implica delirios muy superiores a aquellos contenidos en el propio mito rusoniano. Pinker atribuye (nuevamente al modo idealista de Hegel que reifica las representaciones e ideas como únicas protagonistas de la historia) barbaries y despotismos al despliegue histórico de esencias como el buen salvaje que parecen regir místicamente los devenires y azares humanos.

En fin, el único visible hilo conductor entre los mitos del buen salvaje, la tabula rasa y el espíritu en la máquina es la estrategia hermenéutica de prescindir de cualesquiera diferencias históricas de orden empírico (haciendo tabula rasa de las mismas), fabricando un imaginario del mal para uso exclusivo de las necesidades internas de la propia teoría que destella así, liberada de cualesquiera excrecencias materiales, como divertida e improbable encarnación de un buen salvaje, a salvo de cualesquiera azares, corrupciones, eventualidades y contingencias que enmarañen o compliquen la comprensión definitiva de los asuntos humanos. De esta guisa, esta vez sí, la tabula rasa, el buen salvaje y el espíritu en la máquina hacen de las suyas rindiendo paradójicas y sustanciosas plusvalías.

Seguir manteniendo los ideales de la tabula rasa contra las evidencias de la biología y la psicología evolutiva, negando las relativas diferencias de género no sólo anatómicas, la agresividad de nuestra especie o las naturales desigualdades de inteligencia (entre otras cosas), habría llevado a graves inconsecuencias en la educación o la práctica judicial, creando culpabilidades en muchos padres o exonerando a peligrosos psicópatas. La creencia inconsciente en la tabula rasa y en la radical maleabilidad de la mente humana pervierte la educación, la crianza infantil y el mundo de las artes; atormenta a las madres que trabajan fuera de casa y nos ciega frente a nuestras naturales limitaciones intelectuales y morales. Se trata de un dogma antivital y una abstracción antihumana que niega nuestra auténtica naturaleza.

Nadie va a discutir la existencia de prejuicios sociales derivados de la cultura de la queja y que tienden a imputar automáticamente a una infancia desgraciada o a la miseria capitalista flaquezas o debilidades humanas, a menudo responsabilidad exclusiva de los propios individuos, pero también es cierto 
que un mínimo sentido de perspectiva histórica no debería permitirnos demasiadas alegrías al demonizar algunas ingenuidades sobre la tabula rasa. No olvidemos que más del $99 \%$ de la historia de la humanidad se caracteriza por haber creído abrumadoramente en una tabula abigarrada diseñada por los dioses y en diferencias abismales tanto entre hombres y mujeres como entre los diferentes grupos étnicos.

Ahora bien, ¿contra quién va dirigida esta demonización de la tabula rasa? Contra el llamado espíritu progresista. Como decía el taimado R. McKie (The Observer, 15, 2002) cualquiera capta el mensaje. Si no fuese por los marxistas, los profesores, los trabajadores sociales y las archifeministas no habriamos mirado a veces con malos ojos a los niños superdotados, ni negado que las mujeres tengan menor capacidad para rotar mentalmente figuras geométricas, ni liberado a criminales psicópatas pensando que el mal es un producto de la sociedad.

Al final, pues, la cosa ya no se parece tanto a un riguroso debate intelectual sino a un feroz ajuste de cuentas entre diferentes posiciones de poder en la vida académica y cultural, con profusión de guiños mediáticos a un público al que se intenta seducir con toda suerte de embelecos, mixtificaciones y patrañas.

Cuando Pinker rechaza en nombre de universales psicobiológicos la existencia de culturas reificadas como sistemas de signos arbitrarios que existen al margen de las mentes de las personas, sólo tiene parte de razón si reducimos el mencionado doble alcance de la cultura a su primera dimensión ontológica, de mundo relativamente cosificado y, por así decirlo, objetivable, reproducible y relativamente exportable a otras latitudes y pueblos. Ciertamente, sin naturaleza humana no existe ninguna cultura. Pero aun así, qué duda cabe, la democracia ateniense posee (como todo fenómeno cultural) una existencia ontológica objetiva, como una compleja institución política ligada a cierta configuración de grupos sociales, a cierta organización económica y a ciertas legitimaciones filos 6 ficas. Pues todo ese entramado existe no sólo en la mente de los ciudadanos del Ática (en sus recuerdos, actitudes y expectativas) sino también fuera de sus mentes: de hecho, como es sabido, la cultura democrática ateniense se impuso con desigual éxito en toda la cuenca mediterránea y sin duda ha influido en nuestras modernas instituciones políticas.

Ahora bien, el verdadero modelo estándar de ciencias sociales (si pensamos en las ideas de F. Boas y el mejor Durkheim, para no hablar de M. Weber o Bourdieu) jamás reduciría la democracia ateniense (ni cualquier otro fenómeno social) a un fetiche reificado, auto subsistente y flotante (al modo de una mente supraorgánica), sobre las espíritus de sus pasivos usuarios; sino que, por el contrario, junto a esa vertiente de objetividad social, relativamente autónoma, insistiría en que la cultura democrática ateniense era, al mismo tiempo, inseparable del peculiar aprendizaje erótico de sus adolescentes (toda la filosofía de Platón se orienta a esa paideia, disciplina y enseñanza); de los deseos que impregnaban hogares y gimnasios; de la hybris emocional suscitada por dioses y leyendas; de los temblores al escuchar las gestas de los héroes conmemoradas por los poetas

EMPIRIA. Revista de Metodología de Ciencias Sociales. N. ${ }^{\circ} 11$, enero-junio, 2006, pp. 133-171. 
trágicos, custodiados por las Musas; de sus divinas arrogancias sobre su identidad como ciudadanos (diferentes por naturaleza a bárbaros y esclavos) y, en fin, de sus concepciones falogocéntricas sobre el cosmos, el alma, la ciencia, el bien, el arte, la verdad y la belleza.

Ningún modelo estándar (o no estándar) de las ciencias sociales ha prescindido ni puede prescindir de esa segunda dimensión nutricial y uterina de la cultura, en oposición al carácter objetivo, fáctico, separable, memético y relativamente extramental del mundo cultural, a saber: su encarnación como piel dentro de nuestra piel, como deseo imaginario afincado en nuestros deseos y como emoción alojada en lo más hondo de nuestras emociones.

En la actualidad, suficientemente alejados del darwinismo social y de los variopintos racismos, estamos en disposición de reconocer, finalmente, no sólo algunos de esos universales psicobiologicos reivindicados por Pinker, sino también de que todo el mundo (incluido Pinker) reconozca a su vez el carácter biológico de unas racionalidades humanas empapadas en múltiples, ambiguos y contradictorios deseos y emociones culturales $y$, por tanto, en estremecimientos, voluptuosidades, angustias, culpas, fiebres y ensoñaciones (en esto, el viejo Nietzsche no iba muy descaminado).

Y es que la madre de todos los equívocos y malentendidos sobre biología y cultura (en los que incurre también Pinker) es plantear sus relaciones en términos de afirmación (biologicista) o negación (idealista) de reduccionismos. El reduccionismo, ya sabemos, es una cuestión dialéctica de arriba/ abajo. Pero lo cierto es que, a la vista de la evidencia antropológica disponible, no se puede reducir el binomio biología/ cultura a una tópica y simétrica cuestión de reduccionismo /anti reduccionismo. En asuntos de vanidades humanas y heridas narcisistas, existe algo mucho más amenazador para ciertos humanismos que la (probable, por lo demás) existencia de genes determinantes de tales o cuales funciones neurológicas que condicionan determinadas formas universales de comportamiento político, intelectual, sexual o moral. ¿Qué puede ser ello?

Sólo una cosa: que aquello que consideramos el corazón de nuestro corazón y lo más profundo de nosotros mismos; aquello que otorga serenidad y sentido a nuestros más íntimos goces y alegrías; aquello que hemos aprendido a ser cuando sabemos, finalmente, quién somos; aquello resulta ser, también y a la postre, un oscuro aprendizaje de que podíamos haber sido otros, de que, en realidad, siempre hemos sido y seguimos siendo también, en parte, otros ${ }^{8}$. Algo que, obviamente, se aplica no sólo a individuos (hombres y mujeres) sino también a grupos, sociedades, culturas y enteras civilizaciones.

${ }^{8}$ Vid Castro Nogueira, L, Castro Nogueira, MA, Morales Navarro, J (2005: 747-778) 


\section{BIOLOGÍA Y CULTURA: LA CONSTITUCIÓN CULTURAL}

No creemos que Dobzhansky fuera aficionado a la paradiástole, pero contrastar términos como evolución y cultura, mostrando cierta insinuación de significados opuestos o cuando menos comprensiblemente separables, requiere de una maestría y de un fino equilibrio, patrimonio de los lingüísticamente más dotados. La frase de Dobzhansky "nada en la cultura tiene sentido sino es a la luz de la evolución" es propia de un honesto y combativo investigador que dedicó su existencia a refutar las ideas racistas de su época, cimentadas en la genética. No debiera sorprendernos, pues, que en uno de sus escritos (en colaboración con Dunn) pueda leerse: "Las diferencias psíquicas y culturales entre los individuos y grupos proporcionan el impulso de esfuerzo creador que conduce a la humanidad a mejores realizaciones" (Dunn y Dobzhansky, 1971: 153).

Sin embargo, desde que se escribieron estas palabras (el original, Heredity, Race, and Society es de 1946) son muchos los chaparrones caídos sobre la polémica naturaleza versus cultura. Hoy se entiende que los términos evolución y cultura, sin ser sinónimos y, en consecuencia, intercambiables, son susceptibles de usarse de manera conectiva e inseparable. De tal forma que el nexo de conexión permite voltear la frase de Dobzhansky y presentarla así: Nada en la evolución tiene sentido sino es a la luz de la cultura.

El problema, aún no resuelto, radica en datar el momento del "nacimiento" e invención de la cultura. En otras palabras, ¿cuándo se hace la cultura elemento constitutivo? Por extensión, se podrían formular otras preguntas que siempre remitieran al origen primigenio cultural, a las causas propiciadoras de la aparición de las culturas en sociedad. ¿Qué sucede antes de que se logre la constitución cultural? ¿En qué consiste el proceso constituyente de la(s) cultura(s)? ¿Cuál es su duración en el tiempo? ¿Es el mismo para todas las culturas? Y la más importante de todas ellas, desde el punto de vista conceptual: ¿qué se entiende por cultura constitutiva?

Si el concepto de cultura constitutiva no se segrega de la conciencia humana, ya que sería ésta la que daría sentido y significación al hacer cultural, puede decirse que la constitución de la cultura ocurrió, en la noche de los tiempos: la friolera (en su consideración más extrema) de unos 3'5 millones de años. Habiendo dejado atrás, unos 40 millones de años, a los ancestros del género Homo, a los que se supone que carecían de conciencia (Coppens, 2005: 19-27). Homo sapiens surge de su diferenciación de otros homínidos que le precedieron (fundamentalmente Homo erectus). Se manifiesta en términos de organización social, capacidad comunicativa, uso de las manos para la confección de herramientas y unos mínimos criterios de simbolización, elementos todos ellos que permiten referir a un cierto nivel de cultura.

El hecho de que la respuesta a la pregunta del origen de la constitución cultural sea especulativa y que la ciencia no pueda precisar su datación con conocimiento de causa - nunca mejor empleada la expresión- significa, qué duda cabe, ignorancia. Pero también imposibilidad. Imposibilidad, porque a di- 
ferencia de la gigantesca explosión en el espacio que dio origen al universo, y que para Weinberg (1982; original, 1977) sucedió en un "cierto momento" hace diez mil millones de años, ${ }^{9}$ en la constitución de la cultura no se produce explosión alguna y no se pasa, por tanto, de la "nada" de la materia inerme al "todo" universal de las galaxias. Por el contrario, la cultura como elemento constitutivo es fruto de un continuum, un proceso acumulativo en el tiempo, de gestos, sonidos, símbolos, voces, usos de las manos, migraciones....(opiniones y teorías hay para todos los gustos), que para nada puede confundirse con un Big-Bang cultural. Ignorancia, porque prueba, a pesar de lo mucho que se ha avanzado, el desconocimiento científico ante determinados acontecimientos. Por ejemplo, todavía es un misterio por qué el hacha de mano achelense, usada por los compañeros africanos de "El niño de Nariokotome" (esqueleto de Homo ergaster - - con concreto de un niño de entre 10 y 12 años de edad-, que vivió hace 1'6 millones de años y que pasa por ser el primer esqueleto de homínido similar al nuestro), tuvo tanta implantación temporal: un millón de años. Ignorancia, también, porque a pesar de que no se sepa fielmente, en cuanto a su proceso en el tiempo, de qué forma procede la evolución, no se quiere incurrir en pronunciamientos creacionistas. Que haciendo gala del hecho de residir en la autocerteza y, paralelamente, confundir(se) con mucha seguridad, como en el caso de Ussher (que veremos más adelante), son capaces de precisar casi al segundo el origen de la tierra.

Lo que si parece cierto es que Homo sapiens o, dada la importancia que se confiere al lenguaje como atributo y especificidad estrictamente humana, Homo loquens, requiere de la prueba, del ensayo y del error para ejercitar su cotidianeidad que a la larga facilita su desarrollo cultural. Para Castro y Toro (2004) el aprendizaje social de los homínidos se entiende no exclusivamente en términos de capacidad imitativa, sino en lo que para los autores citados es más relevante: la aprobación y desaprobación de conductas. Con lo cual se podían transmitir de generación en generación unos conocimientos que, de facto, entendemos nosotros, constituirán la formación in crescendo de determinadas ventajas culturales. Al homínido que así actúa, Castro y Toro le denominan Homo assessor. En todo caso, de esta propuesta parece desprenderse que se necesita cierto desarrollo cultural para que se evidencie en sociedad la presencia del Homo assessor. Capaz de desarrollar, a su vez, en esa dinámica evolutiva, la cultura humana. La evolución de Homo erectus a Homo sapiens sería, pues, una presencia continua de "grados sucesivos, una evolución biológica muy especial cuya originalidad (la cursiva es nuestra) sería debida a la acción recíproca que debió de tener sobre ella la evolución cultural que se desarrolló a sus expensas" (Coppens, 2005: 52).

El impacto de la cultura - a medida que ésta se hace más compleja- sobre la biología es mayor. Esta premisa, para nosotros fundamental, no es aceptada por los biologistas, que consideran que la cultura viene a ser un subproducto de

${ }^{9}$ Coppens (2005) lo sitúa más allá en el tiempo: 15.000millones de años; sin embargo, hay que decir que para Weinberg los 10.000 millones de años es una sugerencia formulada en mínimos.

EMPIRIA. Revista de Metodología de Ciencias Sociales. N." 11, enero-junio, 2006, pp. 133-171. ISSN: 1139-5737 
la biología. A nuestro juicio, la cultura no niega la naturaleza humana, pero sí explica aquello que para la biología y el innatismo se hace inalcanzable. Al final del artículo veremos cómo la intersexualidad, (antes conocida como hermafroditismo; también la transexualidad y la homosexualidad hubieran podido utilizarse como ejemplos) tiene distintas lecturas culturales, según la sociedad y la época que se contemple. En otras palabras, los intersexuales, partiendo de bases polimorfas (cromosómicas, hormonales, enzimáticas o de anatomía genital), lo que pudiera presentarse como "biología plural", son aceptados o repudiados socialmente. Así, la "naturaleza universal" de la intersexualidad se hace contingente y la lectura cultural explica lo que desborda a la lectura biologica.

Los posicionamientos a favor o en contra de la naturaleza (o de la cultura) como los viejos rockeros nunca mueren. Tres millones y medio de años después de la aparición de la conciencia humana y, por ende, de los prolegómenos de la cultura constituyente, por rudimentarios que fueran sus niveles, la oposición entre naturaleza y cultura sigue viva. En el proceso los defensores de la naturaleza se atribuyen criterios de cientificidad que niegan a los defensores de la cultura. Tantas veces, la defensa a ultranza de la naturaleza se ha presentado y mantenido como científicamente indiscutible, hasta que observaciones o descubrimientos posteriores invalidaban, también desde la ciencia, los criterios científicos precedentes. Un científico, como Linneo, tan respetado por el impulso que dio a la taxonomía científica, creyó e hizo creer a sus contemporáneos y a generaciones posteriores en la existencia del Homo ferus. Especie de hombre feroz y monstruoso que no había alcanzado la posición erguida, que se sustentaba en cuatro patas que le permitián el desplazamiento (por supuesto no bípedo) y que desconocía las voces que expresan el habla (lenguaje). Otras veces la monstruosidad humana podía mostrarse en forma de cola, el Homo caudatus. (Al lector desprevenido en materia de os coccygis alargados, que a manera de "cola" puede ejercitarse en prácticas coitales como penis succedaneus le remitimos a la lectura de The Sotadic Zone, de Sir Richard Burton o al apunte de Nieto (1996: 357).)

La búsqueda del "flogisto", que una vez hallado hubiera permitido acariciar la inmortalidad a su hallador, no crean ustedes que es cosa de otrora. Es de ayer y de hoy. En el pasado, desde una perspectiva creacionista, Ussher, del que ya se anticipó su nombre, en 1650, precisó, sin titubear, que la aparición de la Tierra, guiada por mano divina, fue el 23 de octubre de 4004 a.c.. Pero "exactitud" por "exactitud", Darwin, que desde la ciencia combatió el principio de la creación, no se mordía la lengua y aseguraba con firmeza (estas cosas o se afirman con rotundidad o dejan de tener sentido) que en un acre medio de suelo se encontraban 53.767 gusanos, ni uno más ni uno menos (Bryson, 2004: 79-81). Los preocupados por saber el número de ángeles que caben en la cabeza de un alfiler tienen en Darwin una buena referencia. Mucho más recientemente, las explicaciones de las causas de la homosexualidad insisten en señalar genes muy concretos, los llamados "genes homosexuales". De entre los distintos autores que se inclinan por la defensa a ultranza del determinismo genético de la homosexualidad, Hamer y 
Coplan (1998), pueden constituir uno de las mejores muestras. Por otra parte, en el año 2000 , desde posicionamientos científicos se defendía irrevocablemente que el genoma humano se componía de cien mil genes. Posteriormente se comprobó que sólo consta de unos 30.000. En todos estos ejemplos prevalece la carga de la naturaleza sobre la cultura; incluso en el de Ussher. En el sentido de interpretar la creación divina como "creación natural", en oposición a la "creación cultural", propia de la conciencia humana.

\section{Entre natura y cultura}

En otras ocasiones, para alejarse de determinismos propios de los enfebrecidos seguidores de las "directrices" de la naturaleza (y de los postulados propios de los vehementes defensores de la cultura), se adaptan posturas intermedias, equidistantes de los extremos de la determinación explicativa. Los representantes de la intermediación ,en función de la parte de la mixtura que se enfatice, la cultura o la naturaleza, les gusta escribir en tono expresivo sosegado, lejos de pronunciamientos radicales ${ }^{10}$. Matt Ridley es un ejemplo apropiado a mostrar: "cualquier genetista que diga que ha descubierto una influencia a favor de los genes y que por consiguiente el ambiente", (es decir, la cultura) "no desempeña papel alguno, está diciendo tonterías. Y cualquier defensor del entorno" (es decir, la cultura) "que diga que ha descubierto un factor ambiental" (es decir, cultural) "y que, por lo tanto, los genes no tienen ningún papel, está diciendo tonterías igualmente" (Ridley, 2004:113).

Para nosotros el debate no es éste. Para nosotros, el debate que interesa es aquél que parte del momento en que se constituye la cultura y observa como ésta, con el paso del tiempo, se hace más compleja. Es decir, del momento en que se salta de lo constituyente a lo constituido y, en consecuencia nos hace presenciar fenómenos culturales y, por ende, sociales. A nuestro juicio, pues, el debate radica en mostrar la respuesta (o iniciativa) sociocultural que se da a (o se toma ante) un fenómeno social. Ya que la complejidad cultural es la característica prevalente que define a Homo sapiens (Wells, 2003).

Las correlaciones existentes entre la genética y la cultura llevó a la eugenesia a establecer el dogma de que los atributos culturales se explicaban por medio de las bases genéticas que les daban origen (Wells, 2003: 174-176). Cuando en realidad lo más probable es que la explicación radique en su contrario: eucultus se impone a eugenus. Decisiones culturales relativas al matrimonio y la propiedad, enfatiza Wells (apoyándose en Seielstad), después de cientos de generaciones han dado luz y significado al hecho de la variación genética y de sus sustanciales diferencias. Además, los atributos culturales no se enfrentan sólo a los

${ }^{10}$ Otros, como Pinker, del que luego volveremos a hablar, se escoran tanto, en la mixtura de sus posicionamientos, a favor de la naturaleza, que se convierten en representantes de la corriente expositiva que nos gusta llamar "natura naturata".

EMPIRIA. Revista de Metodología de Ciencias Sociales. N.$^{\circ} 11$, enero-junio, 2006, pp. 133-171. 
atributos biológicos. Al emplazar los atributos culturales en el tiempo, se observa que el genocidio, por razones de cultura, no ha sido una fantasía y que la erradicación de prácticas culturales -el etnocidio- se ha dado todavía con más frecuencia. Todo ello en aras de una opción cultural, la occidental, que se ha impuesto a las demás. De forma tal que se puede hablar de proceso cultural constituyente, al referimos al remoto pasado, a los inicios del Homo sapiens, como igualmente se puede hablar de un moderno proceso constituyente de cultura. Lo que Sousa Santos (2003:16) llama "modernidad occidental", cuyas características fundamentales no responden a "un paradigma sociocultural global o universal". Por el contrario, "se trata de un paradigma local que se globalizo con éxito, un localismo globalizado".

Sin embargo, nunca como ahora, que se viven momentos de flujos migratorios globales, se han compartido tantas ciudades euroamericanas con culturas diferentes. Aunque el espacio ocupado por unas y otras marque distintos niveles, claras delimitaciones ocupacionales, nítidas separaciones residenciales y transparentes fronteras socioeconómicas. Flujos migratorios que ocasionan que localismos culturales exóticos subestimados por Occidente, hayan instalado su residencia, a pesar de todo, en el exitoso localismo cultural occidental. Lo que supone, entre otras cosas, un incremento de la variedad alimentaria: la alimentación como factor cultural explicitado en la pluralidad gastronómica étnica. Un incremento del número de religiones: la religión como factor cultural heterogéneo no supeditado exclusivamente al catolicismo o protestantismo; mezquitas, sinagogas, templos budistas y shijs, etc muestran la evidencia de la pluralidad religiosa en las ciudades occidentales. Y también la procura política de un voto étnico; factor cultural "exótico", inexistente años atrás, en la cultura occidental que lo demanda: caso de la búsqueda del voto turco en las elecciones del 22 de mayo de 2005 en la Renania-Wesfalia alemana. Todo ello evidencia glocalización e hipercomplejidad cultural.

Así pues, pasamos del dominio interpretativo de la biología al dominio interpretativo de la cultura, sin que ello suponga la negación radical de la primera. La interpretación cultural, ya está dicho, no conlleva la erradicación biológica. Lo que implica es que una vez que la cultura ha quedado constituida, el significado de no importa que fenómeno sociocultural no se ampara en la esencia de la biología. La fijación, la permanencia y la estabilidad que, a manera de motor transhistórico inalterable, hacen las lecturas biologistas de los fenómenos sociales, estrechan y reducen la comprensión de los mismos. Los deseos sexuales, por ejemplo, dejan de ser invariables en el tiempo y, además, abandonan su fijación en la interpretación biológica para devenir plurales y cambiantes en las culturas (Nieto, 2003). Añadiríamos que la expresión de las identidades y de las conductas, en suma, de la sexualidad en su diversidad cultural tampoco es fácilmente sostenible en términos hereditarios. El sentido del humor, las preferencias alimentarias y la afiliación religiosa tampoco parecen ser rasgos que puedan considerarse como demasiado heredables (Ridley, 2004:105). Es más, con independencia de que los rasgos sean más o menos heredables lo que interesa re- 
saltar es la forma en que las sociedades se enfrentan y dan sentido a las manifestaciones humanas de la impronta biológica.

La impronta biológica, por lo demás, está lejos de ser conocida en toda su dimensión y complejidad. Algunas personas "tienen una capacidad genética para absorber educación según las versiones que posean de algunos genes desconocidos" (Ridley, 2004.113). Para este autor (y para tantos otros), la variación genética y las mutaciones son moneda corriente. Es algo tan "normal" que el polimorfismo imperante es motivo de "escándalo" para el psicólogo evolutivo. Desde la perspectiva de la interpretación cultural lo que constituye motivo de escándalo es que la alteración biológica sea reducida a un binario de género, como en el caso de la intersexualidad o, para ser más precisos, de la pluralidad intersexual. De manera que la pluralidad biológica de la intersexualidad se proyecta a través del modelo biomédico de sexualidad y permite la construcción reducida de género. Del reduccionismo cultural de la intersexualidad, propiciada por la biomedicina, no hablaremos aquí (véase al respecto, Nieto: 2003). Sí utilizaremos, como dijimos, la intersexualidad y sus diferencias interpretativas, según muestran los registros etnográficos de distintas sociedades. Lo que nos permitirá negar la falacia naturalista aplicada a la intersexualidad. Lo cual, a su vez, significa que la perspectiva recurrente, mediante la cual la naturaleza determina la cultura, no es otra cosa que un wishful thinking. Sin embargo, se debe enfatizar que en este posicionamiento no subyace en ningún momento el pensamiento oculto de negar la naturaleza humana; es decir, la biología intersexual. Más bien lo contrario. Digamos que la pluralidad biológica del intersexual, tiene su correlato en la interpretación plural de la intersexualidad que se hace desde la(s) cultura(s).

\section{Pinker: un cartesianismo biológico}

Antes de entrar en la exposición del concreto intersexual, veamos, de forma muy general, algunos argumentos que validan la naturaleza como argumentación próxima, última y determinante del quehacer humano en sociedad. Nos volveremos a centrar en La Tabla Rasa de Pinker (2003; original, 2002), libro en que, en términos de cientificidad psicoevolucionista, el autor postula y defiende la naturaleza humana, hasta el punto de hacer de su defensa una reivindicación muy extrema. Siendo el innatismo en general y los mecanismos cognitivos del cerebro en particular, el sustento del planteamiento y de la validación de la naturaleza, el universal explicativo pinkeriano. Su natura naturata

Pudiera decirse que para Pinker la presencia del lenguaje, en todas las sociedades humanas, es la evidencia de la condición innata de Homo sapiens para expresar sus deseos. Estamos, pues, ante una expresión de un universal psicobiológico humano. Planteamiento que respondería, en términos de razonamiento lógico, al universal que tiene la araña en su condición instintiva de entelarse. De forma que el lenguaje, como sustrato genético, anatómico y fisiológico ex- 
plicaría en última instancia el paiuano taiwanés, el castellano, el buruchasqui del valle de Hunza paquistaní y para Wells (2003:56) los 141 sonidos diferentes del idioma ¡xu de los san, los 31 del inglés usado coloquialmente o finalmente los dos tercios de las lenguas habladas en el mundo que tienen entre veinte y cuarenta sonidos diferentes.

Para nosotros, ese lenguaje sin conexión comunicativa, es un lenguaje traicionado. Para Pinker, los sujetos pensantes y hablantes, que por medio de la acción social pueden incidir en la remodelación de pautas culturales, quedan desdibujados. La lengua como producto de la biología, la lengua "biológica", tiene prevalencia en Pinker. El contenido social del lenguaje queda subordinado. Es decir, la intersubjetividad, el sujeto hablante que con intencionalidad actúa en sociedad y tiene la posibilidad de transformar su entorno queda preso de un mecanismo interno que lo controla. Los sujetos de Pinker, anatomicamente preparados para hablar y neurobiológicamente programados para actuar, son más bien sujetos robots. Quedan a mucha distancia del "me comunico, luego existo" de Gergen. Estamos ante sujetos sumidos en la resignación, al ser conscientes de la nulidad resultante de sus acciones. Reflexión que de ser cierta también impediría que la voz del marketing del discurso mediático incidiera en sociedad. Cuando en realidad es la intersubjetividad de la conversación, necesariamente social, la que impregna de significado el lenguaje, desde los orígenes de Homo sapiens. Forma parte del proceso constituyente de la cultura, no como exclamación aislada o autorreferencial sino como parte integrante de la relación intersujetos, generadora de la conversación. Lejos de la violencia dominante, que, de ser asumida, implica la teoría genético-lingüística-innatista de Pinker.

Pinker revaloriza el innatismo del lenguaje incurriendo en lo que pudiera denominarse "monólogo discursivo" con pretensiones de monopolizar su pensamiento. Que en su cartesiana premisa "pienso luego existo" y en su despliegue expositivo parece introducir sottovoce la clásica, arrogante y lapidaria sentencia : "después de mi el diluvio". No cae en la tentación de descatalogar la cultura. No dice que los genes lo expliquen todo y la cultura apenas nada. Pero sí dice que " los seres humanos se comportan flexiblemente porque están programados (...) Hoy es sencillamente un error preguntar(....) si la conducta es universal o varía entre las diversas culturas (...) La conducta inteligente se aprende con éxito porque poseemos unos sistemas innatos" (nuestro subrayado) "que realizan el aprendizaje" (p. 74). En otras palabras, la cultura existe y está conectada a la naturaleza, que la determina en su programación. Pinker no aboga, aparentemente, por un radicalismo naturalista trasnochado que niege la cultura. Pero en el fondo, se trata de una estratagema prosística. Pinker no niega la cultura en la retórica de su prosa, pero, de hecho, la minusvalora -y pudiera decirse que la desprecia-, al considerar la variación cultural como algo que carece de raíces propias, algo, por tanto, superficial. Lo más parecido a una excrecencia. Pinker avala una forma de expresión expositiva que le permite practicar el stop (cultural) and go (biológico).

Todo ello aplicado al lenguaje significa que el innatismo de la laringe y el cableado cerebral en el ser humano constituye la unidad que somete a la diversidad 
lingüística, a las aproximadamente seis mil lenguas existentes, sin respetar sus diferencias. A tenor de sus palabras, Pinker, como Napoleón en sus sueños, se comporta como un conquistador: "todos los aspectos de nuestra vida mental dependen enteramente de sucesos fisiológicos" (p. 75). Manifestación excesiva, desbordante y maximalista donde las haya.

La fuerza de la fisiología determinista que se produce en los tejidos del cerebro no alcanza a explicar las razones últimas de las diferencias culturales. Pinker, de hecho, invierte el razonamiento para apuntar que lo que hay que explicar es el denominador común de la diversidad cultural, la común coincidencia que todas las culturas, por diversas que sean, tienen entre si. En suma, su retórica, a pesar de indicar la inbricación entre la naturaleza y la cultura, queda al descubierto al expresar su idea fuerza y justificar, así, su decantación por la naturaleza como guía que todo lo puede. De ser cierta la formulacion, la antropología no hubiera tenido necesidad de practicar, como ha venido haciendo, la decodificación cultural. De igual forma, la afirmación pinkeriana: "Las personas formadas saben evidentemente que la percepción, la cognición, el lenguaje y la emoción tienen sus raíces en el cerebro" (p. 76) debe desprenderse de su absolutismo enunciatorio y devaluarse. Aunque se acepte la proposición, se tendrá que precisar que las raíces del árbol-cerebro por si solas no permiten que las personas se resguarden en el inexistente sombreado de sus hojas-culturales. El sorprendido Karamazov, que se alegra del surgimiento de un hombre nuevo, pero se lamenta de perder a Dios y que Pinker (p. 75) refiere como anticipo del "suceso fisiologico cerebral" confirmaría, a contracorriente del pensamiento pinkeriano, que hoy estaría sin Dios, pero sería el hombre de antes, un preso, a no ser que la sociedad actual le dispensara de tal condición. Definitivamente, Pinker, en su negación del cerebro, como tabula rasa, adopta posturas tan extremas que le alejan de la moderación del neurocientífico Antonio Damasio (al que recientemente, junio de 2005, se le ha otorgado el premio Príncipe de Asturias, por sus contribuciones en el campo de la investigación cerebral), cuando, mucho más comedido, afirma (Damasio, 2004:282): "la formulación que he presentado" (sobre el cerebro y su funcionamiento) "no debiera disminuir nuestra determinación para controlar circunstancias externas para el beneficio de los individuos y de la sociedad, o nuestra determinación para desarrollar, inventar o perfeccionar los instrumentos culturales con los que podemos hacer que el mundo sea mejor: ética, leyes, artes, ciencias, tecnología".

El sustrato genético, anatómico y fisiológico que, en su evolución, permite que la laringe, en Homo sapiens, se emplace corporalmente en situación que, a diferencia de otras especies, le posibilite el habla, se produce en un momento dado del proceso evolutivo biológico, a partir del cual el innatismo biológico deja de constituir resorte automático determinante para la comprensión del lenguaje. El universal biologico humano del lenguaje viene "modelado" por la cultura, ya se apuntó, en forma de aproximadamente seis mil lenguas. Que, entre otras consideraciones, permitió a Boas pronunciarse en términos de particularismo cultural y, por el mismo motivo, rechazar las teorías relacionadas con el 
evolucionismo de las leyes naturales de Edward Tylor y recogidas en su Primitive Culture. (La cultura primitiva).

En suma, es la biología y la naturaleza las que toman la iniciativa y el desarrollo, ya que la cultura tardó mucho tiempo en alcanzar su momento constituyente. Pero en ese proceso de evolución permanente también llegó el momento de la cultura. Hasta el punto de que "en este desarrollo continuo e inexorable la cultura ha tenido que responder cada vez con mayor frecuencia, en lugar de la naturaleza, a los requerimientos del medio, simplemente porque su respuesta era más rápida" (Coppens, 2005: 61). Esta consideración rechaza el menosprecio de Pinker a la cultura. Así las cosas, no sorprende que las experiencias de vida-sobre todo la volición y las emociones-marcadas, en su momento, por Dilthey y la instancia a la socialidad, la sociality de Overing y Passes (2000), que cobran cada vez mayor predicamento y fuerza en antropología, constituyan la "zona cero" del pensamiento de Pinker. La risa es el nivel menos uno. La naturaleza pinkeriana nos dibuja un Homo sapiens gélido, desprendido de jovialidad, que en su función neurobiológica se olvida del juego, del humor y de los deseos del Homo ludens que en su hacer imprime diversidad lúdica a las culturas. "Animal ridens caracteriza al hombre, por oposición al animal, todavía mejor que el homo sapiens" (Huizinga, 1972:17).

\section{Un pensamiento conservador}

Sintetizando, el etnocentrismo universal pinkeriano es rechazado desde la antropología. La mirada etnocéntrica es una mirada de poder que recrea la sociedad occidental en contextos dispares y ajenos al suyo, de los que se apropia. Además de crear imaginarios, a los que confunde con la realidad. La construcción que hace la sociedad occidental del "orientalismo", que nos dejara escrito Said, es un ejemplo pertinente. Pinker ignora que Malinowski rompió hace ya tres cuartos de siglo el universal del Edipo. Sin olvidar que si la dimensión profunda de la gramática universal tiene su gramática particularizada en distintas lenguas, también los programas afectivos culturales (vergüenza, miedo, culpa, etc.) son societariamente cambiantes. Nuestro núcleo central de sentimientos, el corazón, para los penan y otros pueblos de Sarawak, se sitúa en el higado. Los dani, yali y amumgme de Tenbagapura (Papúa) no parecen conocer el "instinto neuronal" acumulativo, a diferencia de los impulsos ¿o son instintos? de ambición, avaricia y rapacidad de la Freeport, empresa occidental allí residenciada para la explotación del cobre. Los plurales programas afectivo culturales que para Pinker serían reflejo del universal cableado neuronal no dejan de ser una excusa, en forma de axioma, para no dar a la diversidad la relevancia apropiada.

En Pinker, el diseño etnocéntrico y de proyección universal del lenguaje remonta el vuelo, hasta el paroxismo, cuando en el desarrollo de su psicología evolucionista hace de la misma una arquitectura holística que aplica a la política, la violencia y el feminismo. Y sobre todo cuando hace ideología y niega que la hace, 
para hacernos creer que lo que realmente practica es lo que pudiera etiquetarse como "psicogeneticaevolutiva." Es más, la práctica ideológica le sirve para adoptar posturas políticas - que no admite-conservadoras. Cuánto más subraya su presentación biológica, supuestamente única lectura posible a extraer de sus escritos, más radical y ocultamente se manifiestan sus principios políticos

Los procesadores neurológicos, como fin explicativo, de la psicología evolutiva de Pinker, parecen coincidir con la vieja ideología científica de la derecha. Por ejemplo, Pinker se acomoda a la teoría del altruismo recíproco de Trivers y así estrecha la mano a Wilson y a su interpretación sociobiológica. De igual manera, en esa determinación de la naturaleza, como Deux ex machina, Pinker refuta a Gould -ahora que éste no puede replicarle - por la crítica que hizo de la curva de Bell y lo que su determinismo genético implicaba para la interpretación del llamado coeficiente intelectual. Pinker se presenta como científico científico (lo adjetivado del segundo término refuerza lo sustantivo del primero), en tanto que a los científicos sociales (aquí el adjetivo "sociales" debilita al sustantivo que le precede) les reconvierte poco menos que en hechiceros. En Pinker, el hombre se impone al hombre como Occidente se impone a los dani. Su egocentrismo científico corre en paralelo a su etnocentrismo. Neurologiza la vertiente interpretativa sociocultural para descontextualizarla de la sociedad y de la cultura. Muy a pesar de Pinker su propuesta es históricamente contingente. Culturalmente está inmersa en la derecha científica americana. Con toda "naturalidad" ofrece su sesgo biológista y subjetivo, por mucho esfuerzo que haga en presentarse como un científico al "cuadrado", despolitizado. Pinker, como ejemplo recalcitrante de un discurso que le envuelve y fagocita, practica el jensenismo (de Arthur Jensen), el psicólogo de la educación que repudiaba todo lo que no se ajustaba a sus ideas. Hace de Lewontin, genetista no encerrado en la genética, a manera de identidad fortaleza, un errado transeúnte de la ciencia. $Y$ de sus teorías abiertas a la sociedad e impregnadas de cultura, razonamientos pálidos de resultados invalidantes, incapaces de combatir con éxito los principios inviolables que representan la ciencia psicogenética evolutiva pinkeriana. Pinker, en fin, sería una de las múltiples y diversas (re)presentaciones del monomito biologista. Y, desde luego, se sitúa en los antípodas de Sousa Santos, cuando afirma que "todo el conocimiento científico-natural es científico social" ( Sousa Santos, 2003:99).

\section{INTERTEXTUALIDAD Y SEXUALIDAD}

\section{El resurgir de la antropología de la sexualidad y las ciencias sociales}

Decíamos en la reseña de Antropología de la sexualidad y diversidad cultural (Luis Castro Nogueira, 2004), que toda sociedad constituye con sus poderes reguladores explícitos o implícitos, normativos o consuetudinarios, patentes o latentes, el ámbito de la expresión sexual humana, no sólo imponiendo límites y 
restricciones sino también placeres, prácticas, instituciones, rituales, éxtasis y delirios. Pero junto a ese poder de arriba abajo (el poder de las estructuras sociales) existen, como recuerda Nieto, los individuos con sus contrapoderes reactivos e irreductibles a cualquier papel de marionetas que se pretenda endilgarles: así, la ordenación simbólica que moldea la sociedad y encuadra al individuo no tiene la uniformidad y consistencia que en sí misma sugiere (Nieto, 2003: 20)

Junto a Plummer y otros autores, Nieto reivindicaba más allá de cualquier socialización (al rígido modo durkheimiano o estructuralista), la rica e inevitable presencia aleatoria de espacios personales de ambigüedad, creatividad y desorden que otorgan una mayor complejidad y fascinación al sujeto, no sólo en el plano de la conducta sexual sino en cualquier otra dimensión cultural; algo que se aplica al propio antropólogo y su trabajo de campo: tanto en su deriva como científico, extranjero, ajeno y extraño a la cultura investigada, como en su deriva de ser humano sexuado dotado (igualmente) de deseos, emociones y fantasías no menos construidas social y académicamente ${ }^{11}$. Por ello Nieto terminaba reclamando la resurrección postgenital de los cuerpos en su ingenua incorrección y radical ambigüedad. Si hemos llegado hasta aquí, no es para invocar e hipostasiar ahora, nuevamente, un protagonismo exclusivo de los imaginarios (por muy constructivistas que sean) sino que hay que reivindicar el papel irreductible de los individuos, esa imprevisible creatividad, esa risa y esa incapacidad para encajar en nichos prefabricados ${ }^{12}$.

En otras palabras, ya no se concibe que los discursos sobre sexualidad sean en su significación exclusivamente culturales. A los discursos debe incorporarse la significación subjetiva. Los individuos, como actores sociales, no se sujetan al guión cultural parasitariamente, como lapas humanas. Antes al contrario, también hay en ellos capacidad innovadora. Que les permite crear, disentir y diferenciar. Enjuiciar, valorar y dar sentido y significado diferenciado a conductas y prácticas físicamente "idénticas" y "similares"... Habiéndose pasado de una innovación subjetiva titubeante en los primeros momentos del construccionismo social, a la más reciente disidencia individual formulada por la teoría "queer" (Ibidem: 35)

11 Por un montón de razones que van desde prejuicios epistemológicos sobre una observación objetivadora en peligro por todo aquello que tenga que ver con los demonios del sexo, el puritanismo protestante, el colonialismo, el racismo y las posibles represalias académicas, lo cierto es que la tarea de los escasos etnógrafos y antropólogos de la sexualidad, se realizo (incluida la del padre fundador Malinowski) sin experiencias sexuales directas (aunque no sin la contribución de sus fantasías de voyeur, a juzgar por los testimonios del diario del propio Malinowski. En este sentido, Nieto señala: la sexualidad del "voyeur" participante cobra cuerpo cerebral en Malinowski (43) (...) Sin embargo, el cuerpo del etnógrafo, como Santa Teresa en su vivir, estaba sin estar en él; estaba en cultura pero no en su dimensión completa. Sexualmente era un cuerpo inactivo, sin entrar en contacto con el nativo. De la sexualidad solitaria del etnógrafo, como acto reflejo de la fantasía o el pensamiento, no se sabe. No hay registro alguno. La antropología también guarda sus secretos canclaves codificadas (42-3)...

${ }_{12}$ Antropológicamente, la sexualidad no necesita devenir orquesta, siempre lo fue. Otra cosa es que su interpretación se hiciera con un solo instrumento (Ibidem: 36 )

EMPIRIA. Revista de Metodología de Ciencias Sociales. N. ${ }^{\circ} 11$, enero-junio, 2006, pp. 133-171. 
Los escritos feministas, gays y lésbicos han deconstruido la heterosexualidad como exclusivo paradigma dominante. De nuevo, se nos advertía que la construcción social de la sexualidad no implica - ni espera- que sus "arquitectos" construyan todos de la misma forma (Ibidem: 36). Nieto, finalmente, resumía en tres grandes itinerarios el nuevo paradigma constructivista: la cultura como transformación de la biología, la cultura como entidad interpretativa predominante y la cultura como determinante explicativo de la sexualidad (Ibidem: 36)

El primer itinerario funciona como una especie de inversión del modelo de influjo cultural: por muy biológicamente predeterminado que esté el deseo sexual, su carta de naturaleza no es ley. La transformación práctica del deseo no es fija, tampoco estable. El producto de esa transformación, es decir, el deseo en acción, es cultural y plural (Ibidem: 37)

El segundo itinerario enfatiza el carácter polimorfo del deseo: el deseo sexual no viene dado en términos de fijación. No es fijo, ni consustancial-dadas sus manifestaciones varias- al sujeto. $Y$ mucho menos a sus experiencias sexuales, que le configuran como actor social de las mismas. Pudiera decirse, incluso, que hay pluralidad de deseos sexuales. Diversidad de la expresión biológica de los deseos (Ibidem: 37)

El tercer itinerario, el más radical, implica como postura interpretativa más extrema, la negación del deseo sexual biológico. Aquí se produce, lo que pudiera entenderse en algunos construccionistas sociales como la liberación corporal del "yugo biológico". La expresión del deseo sexual y de sus múltiples facetas se confiere en exclusiva al "cuerpo cultural". El cuerpo, como tal, lo es en tanto que reside en la cultura. $Y$ en su versión más determinista pertenece a esa misma cultura. Como las culturas no son fijas y estables en el tiempo, tampoco lo son los cuerpos que las forman (Ibidem: 37)

\section{Sexualidad y ciencias sociales}

Hasta aquí, el resumen del ensayo de Nieto. Permítasenos, ahora, esbozar unas cuantas variaciones sobre el significado para las ciencias sociales de este resurgimiento de la antropología de la sexualidad y de sus itinerarios.

El modelo estándar de las ciencias sociales, según la conocida expresión de los psicólogos evolucionistas J. Tooby y L. Cosmides (1995: 19ss), remite a una concepción de las sociedades humanas según la cual lo social sólo puede explicarse por lo social (lo cultural por lo cultural) y no por variables más profundas de orden psicobiológico. F. Boas en antropología y Durkheim en sociología serían los paladines de esta metodología que considera las culturas como sistemas de signos arbitrarios que existen al margen de las mentes de las personas.

Ciertamente, el error más común en algunos enfoques holísticos de las ciencias sociales (con su hipóstasis de una esfera sociocultural casi autónoma y ajena a la sensibilidad y actividad empírica de los individuos) se produce por la incapacidad de comprender el anclaje de las culturas e imaginarios sociales en 
eficaces sistemas psicobiológicos de aprobación/ reprobación de la conducta. En efecto, si se prescinde del aprendizaje emocional, de la educación y socialización (de aquello que Bourdieu llamaba habitus) parece como si las conductas y prácticas (sexuales en este caso) se reprodujesen mágicamente, en una esfera autónoma y mixtificada, al margen de los cuerpos y las mentes de los individuos.

Pero si al modelo estándar de ciencias sociales le resulta estructuralmente difícil (sino imposible) explicar la diversidad sexual humana, a la psicología evolutiva no le ha ido mejor hasta ahora, postulando la selección de módulos o procesadores cerebrales responsables de conductas (más o menos) masculinas/femeninas de nuestros ancestros.

A menudo da la sensación de que muchos sociólogos del modelo estándar (junto, por cierto, con los psicólogos evolutivos que los critican, empeñados en sustancializar biológicamente conductas de género) son incapaces de comprender el auténtico significado del amarre psicobiológico de las prácticas y representaciones culturales: que se trata siempre de representaciones empapadas en un aprendizaje social de deseos, emociones y valores ligados a placeres/ displaceres del sistema límbico, operantes tanto en el territorio de la sexualidad humana como en el de otros instintos básicos. Basten algunas precisiones.

$\mathrm{Si}$, por un lado, ciertas representaciones, usos y prácticas sociales, como el matrimonio mut a, la fellatio ritual entre los sambia, la práctica erótica de los hijra de la India o la de una actual pareja de adolescentes (Nieto: 2003), poseen el aparente poder de desdoblarse como mundo objetivo, extramental, capaz de autorreplicarse y propagarse (relativa autonomía de la esfera cultural, consistencia del imaginario colectivo, software de programas conductuales, epidemiología de representaciones o memética), por el otro, esas mismas representaciones y prácticas poseen igualmente la esencial (fatal) virtud de encarnarse y transmutarse psicobiológicamente: convirtiéndose en piel de nuestra propia piel, escalofrío y deseo de nuestros deseos, carne, emoción, sensibilidad, memoria, fantasía, inteligencia y delirio, recreando valores y oscuras sensaciones en las que se nos va la vida.

Todo apunta a que el escándalo biológico de sapiens, el que sea posible hablar (en términos de Nieto) de itinerarios alternativos a la hora de dar cuenta de la sexualidad humana, se esconde en esta segunda dimensión emocional de la cultura y los imaginarios culturales, multiplicada por la caótica (espontánea) creatividad de los individuos. Pues esa cara oscura, telúrica, de la cultura, se convierte en nuestra peculiar (radicalmente polimórfica) manera de vivir hasta el fondo nuestra biología.

Por ello, tanto las incrustaciones biológicas del modelo biomédico o incluso del modelo de influjo cultural (apelando a genética, instintos, anatomía o fisiología) como el tradicional idealismo filosófico o religioso (invocando ganchos celestes como la pareja esencial Adán y Eva, el Yin/Yang o el eterno femenino) pasan en silencio sobre lo verdaderamente decisivo y que conoce cualquier antropólogo, a saber: que en gran medida aprendemos a desear los deseos, a emocionarnos con las emociones, a percibir las percepciones y a representarnos las 
representaciones, en suma: que lo completamente otro de la cultura es la invención cultural por excelencia y que la cultura no es un mero producto de los deseos humanos (como defiende Pinker) sino que los connstituye, configura y modula radicalmente.

Sin duda, toda la evidencia disponible en la nueva antropología de la sexualidad apunta a que los procesadores y módulos neurológicos seleccionados durante la hominización no han cerebralizado de un modo determinista el género ni los deseos (masculinos/femeninos), sino que, por el contrario, han funcionado como causa/efecto de múltiples conductas, hábitos, prácticas y representaciones a las que poder irse a vivir, dotadas de suficiente consistencia emocional como para dispensar sensaciones, goces, desventuras y esperanzas exclusivamente humanos. Representaciones que (en ausencia de objeto) pueden invadir (mágicamente) nuestra alma con arrobos, ensoñaciones y fantasías extáticas o con letales pesadillas. Por ello, los circuitos neurológicos que relacionan las áreas lingüísticas del neocortex (y en general del pensamiento abstracto) con el sistema límbico (hipocampo y amígdala), permiten la creación de sofisticados vínculos emocionales con todo tipo de numinosos e irreconciliables imaginarios como el amor por los muchachos (de la Grecia clásica o el Japón de los samurai), la veneración mariana de los cristianos, el amor cortés de la literatura provenzal o el intercambio de imágenes pornográficas por la Red.

Lo más sorprendente de nuestra especie (como decía Castoriadis, 1989:244) es que los placeres/ displaceres de la representación se superponen y, a veces superan, a los placeres orgánicos y casi cualquier conducta, práctica o representación puede adquirir para los hombres la virtud de suscitar, sostener y recrear sus voluptuosidades y desdichas. El individuo social es alguien que puede experimentar placer en fabricar un objeto, en hablar con otros, en oír un relato o un cantar, en mirar una pintura, en demostrar un teorema o en adquirir un saber; también en conocer que los otros tienen una "buena opinión" de él e incluso en pensar que ha "actuado bien". Esta transformación tanto de la "fuente" como del "carácter" del placer, que es en sí misma una de las cosas más asombrosas de todas aquellas a las que la psique nos enfrenta, pone en juego una multitud de procesos y de puntos de apoyo.

Dicho de otra manera, el enigma que liga la condición sexual psicobiológica del hombre con la mareante diversidad cultural etnográfica sólo puede comenzar a pensarse cuando seamos capaces previamente de refutar cualesquiera estrategias tanto psicobiológicas puras como socioantropológicas puras para prescindir de la complejidad, buscando aquello donde se anudan y contaminan (mutuamente) ambas perspectivas

Por ello, la espléndida y tardía genialidad de Foucault revelando ( $¡$ a finales del siglo XX!) el carácter deseante, poético, creativo, productivo ( $\mathrm{y}$ no únicamente represivo) de los discursos y prácticas sobre la sexualidad: un poder microfísico que fascina con sus razones, con sus verdades, con sus industrias y con sus dispositivos culturales; un poder que inventa deseos seduciendo (además de prohibir) y un poder que fascina y hechiza creando emociones (además de so- 
juzgar), tiene mucho de victoria pírrica para las aspiraciones de buena parte de la tradición sociológica, no sólo en el campo de la sexualidad humana.

Sólo la herencia nietzscheana permitió a Foucault navegar entre la Scyla (del tópico represivo y la violencia coercitiva) y la Caribdis (de una misteriosa, proteica e inagotable creatividad sexual). Un poder, el del sexo (y sobre el sexo) que se dice y se experimenta de muchas maneras y ya no viaja sólo como dominio superestructural de arriba/ abajo sino que vive, se reproduce, se inventa y despliega dentro de magmáticos juegos sexuales; brota espontáneamente y se pervierte entre parejas heterosexuales y homosexuales, en el corazón mismo de la identidad de gays y lesbianas, en el vínculo entre el guerrero azande y el jovenzuelo que lo asiste o en la ambiguiedad transgenérica de los hijra.

Pero es que, además, ese poder no sólo es microfísico, localizado y capilar (alejado de los dogmas superestructurales) sino que se crea y recrea, se afirma y se niega por (y en) diferentes sujetos desigualmente sexuados, grupos y clases, situados en lugares diversos del espacio/tiempo social, produciendo fascinantes efectos de autoconocimiento, hechizo y verdad que lo legitiman y relanzan, aureolando de fascinación y ensueños todo género de prácticas y representaciones sociales.

En suma, lo que permitió el indudable encantamiento suscitado por el mensaje foucaultiano no fue otra cosa que una reluctante y extraña obviedad, tan accesible a muchos antropólogos y observadores de la humana naturaleza (artistas, dramaturgos, poetas y novelistas) como oculta a la voluntad de poder de cierta tradición sociológica, a saber: que por razones probablemente inscritas en nuestra psicobiología (evolutiva) las conductas, discursos y representaciones de los seres humanos son siempre representaciones ligadas cultural, imaginaria, azarosa e inextricablemente con deseos, emociones y valores socialmente aprendidos que originan placeres y displaceres exclusivamente humanos.

Esto por lo que respecta a las deudas de las ciencias sociales con la psicobiología evolutiva. Pero lo mismo sucede con las deudas de la psicología evolutiva con la socioantropología. Algo que puede resumirse en una sola cláusula: cualesquiera módulos o procesadores lingüísticos, lógicos o emocional/ valorativos que puedan postularse ( $\mathrm{y}$ descubrirse!) en la evolución del cerebro homínido sólo pueden operar con el proteico software que constituye la insoportable levedad ontológica de las culturas humanas.

En una palabra, los psicólogos evolutivos (el libro de Pinker es un buen ejemplo) deberían reconocer (jugando con una ilusión) que cuando se haya completado el conocimiento de la naturaleza psicobiológica del hombre, ésta sólo puede funcionar o, al menos, sólo ha funcionado hasta ahora, vinculada a lo que con mayor o menor acierto ha venido denominándose cultura.

Y si Foucault tuvo que reconocer la indeterminación esencial (siempre imprevisible) que liga los efectos de poder (no sólo en el ámbito de la sexualidad) con las estructuras sociales pero también con la fascinación del deseo, las emociones, los placeres, los discursos, la verdad y el sujeto, del mismo modo Barkow, Tooby, Cosmides y Pinker han de reconocer la irreductible mediación so- 
ciocultural de muchos deseos (y emociones humanas) ligados a diversos imaginarios, absolutamente decisivos para la memoria, el autoconocimiento y el destino de nuestra especie.

Señala C Geertz: Esto significa que la cultura, más que agregarse, por así decirlo, a un animal terminado o virtualmente terminado, fue un elemento constitutivo y un elemento central en la producción de ese animal mismo(.. ). El perfeccionamiento de las herramientas, la adopción de la caza organizada y de las prácticas de recolección, los comienzos de organización de la verdadera familia, el descubrimiento del fuego y, lo que es más importante aunque resulta todavía extremadamente difícil rastrearlo en todos sus detalles, el hecho de valerse cada vez más de sistemas de símbolos significativos (lenguaje, arte, mito, ritual) en su orientación, comunicación y dominio de sí mismo, fueron todos factores que crearon al hombre un nuevo ambiente al que se vio obligado a adaptarse (Geertz, 1995: 54)

Frente al modelo estándar en ciencias sociales, puede afirmarse, sin embargo, que la sensibilidad y mirada de la antropología se mueve en un territorio categorial más atento al alcance vertiginoso y abismático que supone para la subjetividad personal de cualquier individuo (al margen de sexo, constitución física, e instintos) la total inmersión en cualquier magma imaginario o cultural. A su poder de constituir y transformar a los individuos de arriba abajo, de hacerles nacer por segunda vez. Algo que nos conduce, nuevamente, a cuestionar las tesis de S Pinker y su recuperación de una naturaleza humana (supuestamente) negada por las modernas ciencias sociales.

\section{Intersexualidad y cultura}

La intersexualidad constituye una considerable variación cromosómica (Nieto, 2003). Intersexuales, hermafroditas o pseudohermafroditas (términos que suelen usarse indistintamente) representan ese polimorfismo que tanto preocupa a los psicólogos evolutivos. "Los genes no sólo están relacionados con la herencia, también lo están, y con la misma intensidad, con el ambiente" y además "hacen posible la cultura" (Ridley 2004: 206). Sin embargo, en intersexualidad, la comprensión genética que facilitaría la diversidad cultural hace posible su negación. El modelo biomédico occidental sustentado en la necesidad de acomodar la variación cromosómica de la intersexualidad a la exigencia sociolegal suprime la pluralidad intersexual y la reduce a una mínima expresión dual. La cirugía se encarga de la transformación de la anatomía de los genitales ambiguos. Genitales de varones con aspecto "femenino", como en el llamado síndrome de Morris y genitales de mujeres con aspecto "masculino", como en el síndrome adrenogenital, deben reconvertirse, siguiendo el protocolo biomédico, para eliminar la ambigüedad que les caracteriza. Hormonal y quirúrgicamente transformados -refiriéndonos exclusivamente a situaciones que no implican riesgos para la salud- los intersexuales devienen varones y mujeres "en toda regla". 
Con ello el modelo biomédico se ajusta al binario de sexo/género de las sociedades occidentales. Se ignoran, así, los ejemplos de sociedades no occidentales que discrepan de la construcción social reducida del binario occidental (Nieto, 2004). A los intersexuales, siguiendo indicaciones de Money, para quien el género se aprende como una lengua nativa, se les debía hacer crecer como varones o como mujeres. A los dos años, como muy tarde, se tenía que proceder a la asignación de su identidad. A los varones, por medio del aprendizaje social, se inculcaban roles de género masculino. A las mujeres, por medio del mismo aprendizaje, se inculcaban roles de género femenino. En el proceso a los intersexuales se les privaba del conocimiento de su condición. Y cuando la descubrían, una vez adultos, reaccionaban de forma diversa. Rabia, confusión, resentimiento, depresión, inestabilidad emocional, tendencias suicidas, eran las reacciones más frecuentes.

La trayectoria occidental de ocultar a los propios interesados su condición intersexual, sin resistencia alguna, se prolongó en el tiempo, hasta la década de los 90. Entonces se elevan, del silencio y la invisibilidad, voces discrepantes del procedimiento y protocolo biomédico. Especialmente la de Cheryl Chase, intersexual que adoptó y sigue adoptando una postura muy activa en defensa de la intersexualidad, aglutinando en torno a su persona un grupo de intersexuales y fundando, en Estados Unidos, la Intersex Society of North America. Al frente de tal asociación ha tenido ocasión de "contemplar de primera mano cientos de casos en los que una medicina bien intencionada pero descaminada ha aumentado, en lugar de aliviar, las dificultades del hecho de nacer intersexual" (Chase, 1998:385). Colectivos de características parecidas surgieron posteriormente en otros países occidentales. Las premisas capitales de todos ellos, siguiendo criterios del colectivo fundador, fueron la de erradicar la intervención quirúrgica en la infancia y respetar la decisión a tomar por el intersexual en su etapa adulta. Y también la de romper con el secretismo y el aislamiento de la intersexualidad. Las premisas apuntadas tuvieron un apoyo (in)esperado de algunos profesionales del sector biomédico y del derecho (véase, p.e., Glenn Benn y Diamond, 2000). Actuando de esta forma, reconociendo abiertamente la intersexualidad, el binario de sexo/género queda desestructurado.

Proceder así significa para los intersexuales incurrir en un proceso de ida y vuelta. Primero, porque cuando son conscientes de su intersexualidad, lo son a través de la indagación continuada y directa, a lo largo de los años, de lecturas de información médica. Otras veces, la toma de conciencia intersexual se alcanza indirectamente, por medio de información médica suministrada a los padres, y a la que llegan después de mucho sospechar, mucho insistir y mucho sufrir. La información propiciada por otros intersexuales es más tardía. Después, cuando se confirma su condición, y a tenor de los padecimientos personales y de los malos resultados que supuso seguir directrices marcadas por la medicina, revocan la etiqueta médica que les hacía pasar por varones o mujeres, para devenir intersexuales. Puede decirse que a los médicos les atribuyen su identidad y a los médicos se la quitan. Queda al descubierto, así, que la forma de intervenir de la 
medicina ante el niño intersexuado revela menos de la intersexualidad que de la incomodidad médica y social ante la intersexualidad (Crouch, 1998).

Además, de esta forma, los intersexuales dejan de caracterizarse exclusivamente como objeto de estudio para reconvertirse en sujetos de conocimiento. El rechazo identitario previo y la asunción de una nueva identidad, son, sin embargo, decisiones necesarias e imprescindibles para ese "renacimiento" más acorde con su identidad y realidad personal. "Un viaje doloroso para reclamar su propio ser" (Preves, 2003:99). Es más para los intersexuales entrevistados por Preves, el estigma perpetuado en el tiempo y la identidad maltratada (spoiled identity), una vez que se internaliza y asume la intersexualidad, desaparecen. Asumir la intersexualidad en contra del diagnóstico médico y su criterio diferenciador identitario, en términos de masculino o femenino, logra dos aspectos sustanciales en la vida de los intersexuales. Por un lado, el sentido de la adquisicion de poder que les proporciona la evaluación que hacen de si mismos. Por otro, profundizar en el convencimiento de que la intervención médica de la comprensión de la intersexualidad más que mitigar sus padecimientos ha contribuido a crearlos.

Los intersexuales rehúsan hacer suyo el binario de géneros y con ello la identidad refugio que les confiere la medicina. Ante esa identidad monista sin fisuras, fija e irreversible, ajena a su decision, el intersexual opone su criterio propio con fluidez identitaria de género. Así, las reglas identitarias de género se desencuadernan. La intersexualidad, al igual que la transexualidad, constituye un espacio social de pertenencias múltiples, de subjetividades diversas, de manifestaciones plurales -a veces contrapuestas-, de expresión cultural transgenérica y polimorfa. Los intersexuales dan vida pública y, por tanto, social al reconocimiento de su polimorfismo genético, que lejos de preocuparles, lo expanden y en su expansión se desprenden del estigma impuesto.

El activismo social de los intersexuales es un claro ejemplo de intencionalidad: resolver sus problemas y también lograr sus deseos, ante la ineficiencia de las resoluciones diagnosticadas por la medicina. Una actitud política y, por lo demás, paradójica, porque la movilización intersexual se da en momentos en que la profesión política en las sociedades occidentales se devalúa y la participación ciudadana en asuntos de interés político - salvo ocasiones muy puntuales, como las movilizaciones en contra de la guerra de Irak - se reduce, poco menos que, al mínimo democrático: depositar un voto cada cierto tiempo. Y porque precisamente la movilización intersexual se produce para presionar la toma de decisión legal que contemple sus derechos. Hecho que en un ámbito como el intersexual resultaba pocos años atrás impensable.

Los intersexuales, en su movilización para obtener los derechos civiles que se les niegan, no se acomodan al criterio pinkeriano de "quien tenga que tomar decisiones reales se habría de preocupar sólo de lo que es, no de cuál fue su causa" (Pinker, 2003:223). Y mucho menos, si cabe, a la afirmación que hace Pinker (p.302) cuando indica: "la idea de que los estereotipos son inherentemente irracionales se debe más a una condescendencia hacia la gente corriente que a una 
buena investigación psicológica" Los intersexuales no pueden identificarse con afirmaciones de tal calibre porque de hacerlo aceptarían la marginación social, porque discrepan del modelo biomédico, porque quieren ser visibles y audibles, porque la intersexualidad social de los navaho, como veremos infra, no es la intersexualidad social de los pokot y porque la excepción no confirma la regla. Es más, si los intersexuales siguieran a Pinker y no se preocuparan de las causas de sus padecimientos significaría el alargamiento de los mismos. Y si Pinker aplicara su propia "medicina" a los intersexuales, preocupándose de lo que son e ignorando las causas por las que llegaron a la preocupación, negaría sus fundamentos teóricos. Negaría la biología de la intersexualidad para abrazar, sin querer, la interpretación cultural. Porque de la premisa pinkeriana, más arriba indicada, se desprende que no importaría el innatismo intersexual sino la lectura cultural que se haga de la intersexualidad. Que es como decir "hemos logrado la cuadratura del círculo".

¿Qué ha significado la intersexualidad en sociedades no occidentales? Los ejemplos transculturales que brinda la antropología permiten comprobar que la respuesta cultural que las sociedades no occidentales dan a la intersexualidad difiere de unas a otras. Así, en un artículo pionero sobre el estatus de los hermafroditas (o pseudohermafroditas), nombres que, como indicamos, hasta recientemente recibían los intersexuales, Hill afirma que la cultura de los navaho de Nuevo Méjico les reconoce más oportunidades, en relación a la consecución de gratificaciones personales y materiales, que las concedidas al resto de los miembros de la sociedad. El término usado para hermafrodita, nadle, es el mismo que los navaho usan para referirse al travesti (transvestite, en el original). Sin embargo, matizan entre "el nadle verdadero" (the real nadle), el hermafrodita y el que pretende ser nadle, el travesti. A pesar de la matización, el estatus de hermafroditas y travestis culturalmente es el mismo. Las familias que cuentan con un nadle son muy afortunadas. Y respetadas. Respeto que se traslada al propio nadle y que crece a medida que envejece. Hay que señalar, no obstante, que esta actitud respetuosa hacia el nadle estaba cambiando cuando se llevó a efecto el estudio (Hill, 1935). El respeto cedía terreno al ridículo. De todas formas, el estigma y los tabúes sexuales que los navaho asignaban a las personas "normales", en el caso de los nadle no existían. Sus actividades sexuales no eran censuradas, se respetaba su promiscuidad. Las relaciones sexuales de los hermafroditas se realizaban sólo con hombres. Vestían generalmente como mujeres, se sentaban como las mujeres y no se casaban. De alguna forma, los hermafroditas se consideraban seres sagrados.

Hay que esperar -si no andamos equivocados- hasta 1964, es decir, casi treinta años después del artículo de Hill, para encontrarnos con otro artículo sobre intersexualidad de contenido antropológico (Edgerton, 1964). El autor, Edgerton, abandona el uso del término hermafroditismo y, en su lugar, utiliza "intersexualidad". Lo que indica, cuando menos, que sexualmente algo se estaba moviendo en la sociedad norteamericana (de donde procede Edgerton). Desde luego los informes Kinsey ya se habían publicado. Ya circulaban las primeras 
aportaciones sobre niños intersexuales de Money y de igual forma se conocían los escritos sobre "pacientes" intersexuales de Stoller. El propio Edgerton rinde tributo al artículo de Stoller, Garfinkel y Rosen (1960) sobre identidad/identificación sexual de un intersexual.

Desde las premisas que la sociedad americana aporta, Edgerton estudia la intersexualidad de la sociedad pokot de Kenia. Las conclusiones que alcanza suponen un giro de ciento ochenta grados en relación a las de Hill. La cultura pokot no es tan permisiva con los intersexuales como la cultura navaho. Para una familia pokot, el hecho de parir un intersexual es muy desafortunado. Es como alumbrar a un freak, al que se debería matar. Lo que no siempre se lleva a cabo por considerar que se trata de un designio de Dios: "Dios cometió un error" (p. 1292). Sererr es el nombre que los pokot dan a los intersexuales, algunos de los cuales usan vestidos de mujer y otros de hombre. El significado de sererr refiere a hombre y mujer, pero también a ni hombre ni mujer. En ningún caso a los sererr se les considera personas. Además, no forman parte de aquellas actividades que para los pokot son relevantes. Los sererr no participan de los juegos sexuales de los niños y adolescentes, no son circuncidados y no pueden tener hijos. "Los sererr ni desean ni se les permite experiencia sexual alguna" (p. 1295). "Para ser un pokot de verdad debes ser muy habilidoso sexualmente". Finalmente, resta añadir, en esta apretada síntesis, que a los intersexuales pokot no se les concede ningún poder sobrenatural.

Quince años después del artículo de Edgerton, en 1979, Imperato-McGinley et al., publican el estudio de los guevedoche dominicanos. Los autores refieren treinta y ocho casos de pseudohermafroditas masculinos (es la terminología utilizada) de tres pueblos del sudoeste de la Republica Dominicana. La explicación de estos pseudohermafroditas se hace desde la perspectiva biomédica. Debido a la deficiencia de la enzima 5 alfa reductasa, que les impide tener niveles adecuados de dihidrotestosterona, los guevedoche nacen con genitales de aspecto femenino. Dieciocho de los treinta y ocho pseudohermafroditas fueron educados sin ninguna ambigüedad como mujeres. Después de la pubertad, diecisiete de los dieciocho casos adoptaron identidad de género masculina. La conclusión que alcanzan los autores es que cuando el cerebro del embrión en el útero de la madre, del recién nacido y del púber está sometido a niveles normales de testosterona "parece contribuir sustancialmente a la formación de la identidad de género masculina" (Imperato-McGinley et al., 1979:1233).

La información "sociocultural" viene dada en el artículo en forma de un escueto apéndice. Y de alguna forma sirve, dada la exposición que se hace de las prácticas sociales de los pueblos de pertenencia de los guevedoche, para reafirmar que la identidad de género masculina se debe a los andrógenos que contribuyen a la formación identitaria de forma evidente y definitiva (p. 1236).

Herdt (1990) rechaza la explicación del equipo de Imperato-McGinley, por ser unicausal, biologicista y, en consecuencia, reduccionista. En Republica Dominicana se toman muestras de sangre y orina que se analizan ulteriormente en la clínica, con lo que se desocializa al guevedoche y se descontextualiza la 
identidad de género. La mirada clínica se impone a la mirada antropológica y se aplica lo que Herdt (tomándolo de Klaus y Kennel) llama "cultura de hospital" (p. 438). Para Herdt, en oposición a Imperato-McGinley y a la explicación biomédica que aporta, el sistema cultural del guevedoche y "la ontología del pueblo incluye una categoría tercer sexo que desmiente las respuestas biológicas" $\mathrm{y}$, además, la transformación corporal que se produce en torno a los doce años no es de mujer a hombre, sino algo muy diferente, de "mujer -posiblemente educada con ambigüiedad - a hermafrodita identificado con varón" (Herdt, 1990: 437-438).

Por otro lado, una interpretación muy diferente del hermafroditismo guevedoche de Imperato-McGinley es la que hace Herdt (1990) del kwolu-aatmwol de la sociedad sambia de Melanesia. El kwolu-aatmwol sambia es un pseudohermafrodita masculino que, como el guevedoche dominicano, muestra deficiencia de 5 alfa reductasa. De bebés no se les asigna la identidad de varón, se les reconoce como kwolu-aatmwol o como mujeres. Para los sambia constituye un tercer sexo que les causa tristeza (se supone por no ser deseados). Los kwolu-aatmwol son aceptados socialmente. Aunque del relato de Herdt se desprende que con cierta ambiguiedad, ya que en caso de llegar a ser chamanes o jefes de su grupo en las luchas interétnicas se les respeta y distingue, en caso contrario se les desprecia. La sociedad sambia no siente repugnancia hacia ellos, pero se les considera como si se tratara de una extravagancia misteriosa y de niños sus compañeros se burlan de ellos y les humillan por no tener pene. Además, los kwolu-aatmwol no cumplen los seis grados de iniciación que los sambia reservan para sus varones (Herdt, 1999:439-440).

El sexo anatómico ambiguo, con fronteras genitales borrosas, al ser aceptado culturalmente como un tercer sexo, tanto en la sociedad sambia como en República Dominicana, supone que cuanto mayor sea la flexibilidad, es decir, la aceptación polimorfa de los sexos, menos problemática resulta la intersexualidad. Por el contrario, cuanto más rígida sea la oposición dual de los sexos, la intersexualidad es más problemática. Parecen verdades de Perogrullo pero la terquedad de la sociedad occidental en admitir este planteamiento obliga a resaltarlo. Los sistemas culturales que permiten una mayor fluidez de géneros hacen más manejables y llevaderas las vidas de los intersexuales. Las dictaduras de género, como cualquier dictadura, también merman, coartan o suprimen la libertad de los sujetos. Los intersexuales deconstruyen estereotipos y ponen en un brete la "natural" heterosexualidad. Desestabiliza su categoría de ser algo absolutamente inmutable, transhistórico y transcultural. La naturaleza demiurga que todo lo puede con su exceso de innatismo, para Pinker en forma de amígdala reducida, hipometabolismo de los lóbulos frontales y genes defectuosos, de tratar de explicar la intersexualidad hubiera incluido, es de esperar, la deficiencia de la 5 alfa reductasa. Y se hubiera sobreimpuesto a la diversidad cultural intersexual. Pinker (p. 301) dixit: "La irregularidad” (¿por qué no la diversidad?) "procede del mundo" (¿de dónde si no?) "no de la sociedad ni el lenguaje" (¿no forman parte del mundo?). Es decir, para Pinker, el guevedoche dominicano y el kwoluaatmwol 
son personas irregulares sin sociedad ni lenguaje. ¡Menos mal que proceden del mundo! Los intersexuales dominicanos y de la sociedad sambia, al ser aceptados como tales por sus culturas, rompen el dimorfismo de los sexos, para asumir el polimorfismo sexual. A pesar de que para Pinker (p. 427) "las adaptaciones no se producen por el bien de la especie, sino por el de los individuos y sus parientes (como si se reivindicara la afirmación de Thatcher de que "no existe eso de la sociedad")".

\section{A modo de sobremesa:}

1. A lo largo del artículo se ha tratado de mostrar que la naturaleza y el innatismo no son elementos autosuficientes que expliquen el acontecer cultural, en general, y la intersexualidad, en particular.

2. De igual forma, el modelo biomédico, modelo de orden natural, no explica el sistema cultural intersexual

3. El hecho de que la naturaleza y la biomedicina no expliquen la cultura no supone restar importancia al factor biológico y mucho menos negar la biología y el innatismo. La biología explica categorías biológicas y la neurociencia categorías cerebrales como la antropología explica categorías culturales.

4. Que la enculturación y la socialización se construyan sobre bases naturales (genes, enzimas, hormonas..) no supone reducir la cultura a la biología. Lo contrario es sobredeterminar la biología.

5. Los mismos componentes biológicos, como la 5 alfa reductasa en la intersexualidad, muestran manifestaciones culturales diversas.

6. Las culturas son producto y productoras de construcción social.

7. Las culturas no son inmutables, cambian con el paso del tiempo

8. En consecuencia, las conductas sociales, lejos de ser universales, tienen lecturas diferentes según épocas o espacios culturales. Los intersexuales de la sociedad occidental no tienen la aceptación y el respeto que la sociedad navaho brinda a los mismos. De la misma forma, los intersexuales navaho, debido a la penetración occidental, dejaron de verse por la sociedad como seres sagrados.

9. Los sujetos sociales no son meros autómatas o robots biológicos. Los intersexuales, como sujetos sociales que son, están transformando la realidad cultural: pasan de ser objeto exclusivo de estudio a ser sujetos de conocimiento.

10. La toma de decisiones políticas forma parte de la construcción sociocultural. La aprobación de los matrimonios gays y lésbicos por el Parlamento español es una prueba evidente. Tal decisión no está basada en fundamentos biológicos, lo que desde un punto de vista epistemológico es de gran relevancia. Da la vuelta al argumento que presenta la homosexualidad como un factor biologico inmutable. Y así contribuye a no 
patologizar o culpabilizar la homosexualidad y, además, permite "destruir" leyes (de distintos países) que criminalizan la identidad y la conducta homosexual. En resumen, la ley española, al margen de biologismos, contempla y otorga unos derechos que se venían negando a gays y lesbianas.

11. Los derechos civiles de los ciudadanos están por encima de las subjetividades biológicas. La biología también es una ciencia social.

Terminamos con un sobrepostre que se toma de la mesa de García Canclini (2004: 40) "El paisaje que estamos registrando es de identidades culturales más o menos autocontenidas a procesos de interacción, confrontación y negociación entre sistemas socioculturales diversos". 


\section{BIBLIOGRAFÍA}

BRYSON, B. 2004. Una breve historia de casi todo, RBA Libros, Barcelona.

Burton, R. n.d. The Sotadic Zone, The Panurge Press, Nueva York.

CARrTthers, M. 1995. ¿Por qué los humanos tenemos culturas? Alianza editorial, Madrid.

CASTORIADIS, C. 1989. La institución imaginaria de la sociedad, vol. II, Tusquets, Barcelona.

CAStro, L. y M. Toro, 2004. "The Evolution of Culture. From Primate Social Learning to Human Culture", pp. 10235-10240, en Proceedings of the National Academy of Sciences, Vol. 101.

Castro Nogueira, L., Castro Nogueira, L., Toro, M. Á. 2005. Reseña de La tabla rasa: la negación moderna de la naturaleza humana de Steven Pinker (pp. 38-43), Revista de Libros, 102.

Castro Nogueira, L, Castro Nogueira, M. A., Morales Navarro, J. 2005. Metodología de las ciencias Sociales. Una introducción crítica, Tecnos, Madrid.

CAstro Nogueira, L. 2004. reseña de Antropología de la sexualidad y diversidad cultural (pp 254-259), Empiria, 8.

COPPENS, Y. 2005. La rodilla de Lucy. Los primeros pasos hacia la humanidad. Tusquets editores, Barcelona.

CROuCH, R. A. 1998. "Betwist and Between: The Past and Future of Intersexuality", pp. 372-384, The Journal of Clinical Ethics, Winter.

Chase, Ch. 1998. "Surgical Progress is not the Answer to Intersexuality", pp. 365-392, The Journal of Clinical Ethics, Winter.

Dawkins, R. 2000. El gen egísta, Salvat, Barcelona.

DunN, L. C. y Th. DoBZhANSKY, 1971. Herencia, raza y sociedad, FCE, México.

EDGERTON, R. B. 1964. "Pokot Intersexuality: An East African Example", pp. 1288-1299, American Anthropologist, Vol. 66, N. 6.

García CanClini, N. 2004. Diferentes, desiguales y desconectados. Mapas de la interculturalidad, Editorial Gedisa, Barcelona.

GEERTZ, C. 1995. La interpretación de las culturas, Gedisa, Barcelona.

GlenN BeH, H. y M. DiAmond 2000. "An Emerging Ethical and Medical Dilemma: Should Physicians Perform Sex Assignment Surgery on Infants with Ambiguous Genitalia"? pp. 1-63, Michigan Journal of Gender and Law, Vol. 7, Issue 1.

HAMER, D. y P. COPELAND 1998 Living with our Genes, Doubleday, Nueva York.

HERDT, G. 1990. "Mistaken Gender: 5-Alpha Reductase. Hermaphroditism and Biological Reductionism in Sexual Identity Reconsidered", pp. 433-446, American Anthropologist, Vol. 92, N. 2.

HiLL, W. W. 1935. "The Status of the Hermaphrodite and Transssvestite in Navaho Culture”, pp. 273-279, American Anthropologist, Vol. 37.

IMPERATO-MCGINLEY et al... 1979. "Androgens and the Evolution of Male Gender Identity among Male Pseudohermaphrodites with 5-Alpha Reductase deficiency", pp. 1233-1237, The New England Journal of Medicine, Vol. 300, N. 22.

LEWONTIN, R.; RosE, S.; KAMIN, L. 1985. No está en los genes. Racismo, genética e ideología, Crítica, Barcelona.

Nieto, J. A. 2004. "Globalización y transgenerismo en el Pacífico", pp. 191-221, en José A. Nieto, Pacific Sexualities. Different Sexual Cultures in Asia and Oceania. Sexua- 
lidades del Pacífico. Diferentes culturas sexuales en Asia y Oceanía, Asociación Española de Estudios del Pacífico/AECI, Madrid.

NIETO, J. A. ed., 2003a. Antropología de la sexualidad y diversidad cultural, Talasa, Madrid.

NIETo, J. A, 2003. El resurgir de la antropología de la sexualidad, en Antropología de la sexualidad y diversidad cultural (pp.15-51), en Nieto, José A, edit, Talasa, Madrid.

NiETo, J. A. 2003b. "La intersexualidad y los límites del modelo "dos sexos/dos.

géneros", pp. 69-104, en O. Guasch y O. Viñuales, eds., Sexualidades, diversidad y control social, Edicions Bellaterra, Barcelona.

NiETo, J. A. 1996. Antropología de la sexualidad. Erotofobia y Erotofilia", pp. 357-368, en J. Prat y A. Martinez, eds., Ensayos de antropología cultural, Editorial Ariel, Barcelona.

OVERING, J. y A. PAsses, 2000. The Anthropology of Love and Anger. The Aesthetics of Conviviality in Native Amazonia, Routledge, Londres.

PINKER, S. 2003. La tabla rasa. La negación moderna de la naturaleza humana, Ediciones Paidós, Barcelona.

PinKer, S. 2001. Cómo trabaja la mente, Destino, Barcelona.

PINKER, S. 1996. El instinto del lenguaje, Alianza, Madrid, 1996.

PREVES, S. E. 2003. Intersex and Identity. The Contested Self, Rutgers University Press, Piscataaway, New Jersey.

RidLEY, M. 2004. Qué nos hace humanos, Taurus, Madrid.

Sousa SANTOS, Boaventura de 2003. Crítica de la razón indolente. Contra el desperdicio de la indolencia, Vol. 1, Editorial Desclée de Brouwer, Bilbao.

TOOBY, J. y COSMIDEs, LeDA, 1995. The Psychological Foundations of Culture, en The Adapted Mind (pp 19-136), Barkow, J. H, Cosmides, L. y Tooby, J., edits, Oxford University Press, New York.

WeINBERG, S. 1982. Los tres primeros minutos del universo, Alianza editorial, Madrid.

WeLLs, S. 2003. The Journey of Man. A Genetic Odyssey, Penguin Books, Londres. 


\title{
RESUMEN
}

Este artículo tiene diferentes objetivos. En primer lugar, nos centramos en las ideas de Pinker relacionadas con la psicología evolutiva. Se evalúan las principales tesis de Pinker y en particular su reivindicación de una verdadera naturaleza humana. En segundo lugar, mostramos las falacias que subyacen a su interpretación del binomio biología/cultura y consideramos críticamente la supuesta incapacidad del modelo estándar en ciencias sociales. Finalmente, se desvela la aproximación etnocéntrica, biomédica y conservadora de Pinker y se rechaza desde el punto de vista de la construcción social de la intersexualidad.

\section{PALABRAS CLAVE}

Naturaleza, "Modelo estándar de las Ciencias Sociales", Psicología evolutiva, Intersexualidad

\begin{abstract}
This paper has different aims. First, we focus on evolutionary psychology and, above all, Pinker's ideas. By way of analysis, Pinker's main thesis and specially his vindication of a true human nature is critically evaluated. Second, we show the bias of his theoretical predicaments regarding to the biology/culture binomial understanding. Then, we also take into consideration the (assumed) incapacity, according to Pinker, of the so called social science standard model in order to elucidate the psychological nature of human beings. Finally, Pinker's ethnocentric, biomedical, conservative and ideological approach is revealed. Morover, is refused. Rejection is based on an antropological standpoint:the social construction of intersexuality.
\end{abstract}

\section{KEY WORDS}

Nature, «Social Science Standard Model», Evolutionary Psychology, Intersexuality 